\title{
Political Connections and the Informativeness of Insider Trades
}

\author{
Alan D. Jagolinzer \\ a.jagolinzer@jbs.cam.ac.uk \\ Judge Business School \\ University of Cambridge \\ David F. Larcker \\ dlarcker@stanford.edu \\ Graduate School of Business \\ Rock Center for Corporate Governance \\ Stanford University \\ Gaizka Ormazabal \\ gormazabal@iese.edu \\ IESE Business School \\ University of Navarra \\ Daniel J. Taylor* \\ dtayl@,wharton.upenn.edu \\ The Wharton School \\ University of Pennsylvania
}

October 2019

\footnotetext{
*We thank seminar participants at Cornell, Northwestern, SUNY-Binghamton, Texas A\&M, UCDavis, University of Chicago, University of Minnesota, University of Southern California, University of Utah, and the Securities and Exchange Commission. We thank Joseph Grundfest, and several officials at the FBI, Treasury, and Department of Justice for helpful comments and suggestions. We thank Michelle Gutman, Adam Bordeman, Vikram Dhawam, John Kepler, Richard Knapp, Alex Yuan, Jessica Weber, and Ruizhong Zhang for outstanding research assistance; and Ran Duchin and Denis Sosyura for sharing data on political connections. Data on TARP application amounts used in the paper was obtained through a FOIA request, and is provided in the Internet Appendix. We thank our respective schools for financial support, and acknowledge funding from the Winnick Family Faculty Fellowship at Stanford University, the Marie Curie and Ramon y Cajal Fellowships at IESE, and the Dean's Research fund at The Wharton School. The authors do not have any potential conflicts of interest to disclose, as identified in the Journal of Finance Disclosure Policy.
} 


\title{
Political Connections and the Informativeness of Insider Trades
}

\begin{abstract}
:
We analyze the trading of corporate insiders at leading financial institutions during the Financial Crisis. We find strong evidence of a relation between political connections and informed trading during the period in which TARP funds were disbursed, and that the relation is most pronounced among corporate insiders with recent direct connections. Notably, we find evidence of abnormal trading by politically connected insiders 30 days in advance of TARP infusions, and that these trades anticipate the market reaction to the infusion. Our results suggest that political connections can facilitate opportunistic behavior by corporate insiders.
\end{abstract}

Keywords: Political Connections; Insider Trading; Financial Crisis; Troubled Asset Relief Program; Capital Purchase Program

JEL Classification: G14; G20; G28; G30; K2 
There is an extensive empirical literature that examines the relation between managers' political connections and firm value. Most of this research suggests political connections are associated with a wide range of shareholder benefits, including preferential access to capital and increased likelihood of winning government procurement contracts (e.g., Faccio, 2006; Goldman, Rocholl, and So, 2009; Cooper, Gulen, and Ovtchinnikov, 2010). While the shareholder benefits of political connections are well documented, there is scant evidence on whether political connections facilitate opportunistic behavior by managers and directors (hereafter "corporate insiders"). In this paper, we examine whether political connections facilitate one particular form of opportunism—informed trading. ${ }^{1}$

We examine the relation between political connections and informed trading by corporate insiders within the context of government intervention during the 2007-2009 Financial Crisis. The unprecedented magnitude of the intervention, the substantial impact of the intervention on firm value, and the political nature of this intervention provides a powerful setting to examine our research question. For example, it is now well known that deliberations on government intervention largely took place in private meetings between government officials and insiders at leading financial institutions; details regarding the application and qualification process for funds from the Troubled Asset Relief Program (TARP) were not publicly disclosed; and political connections appear to have played a role in the allocation of these funds (e.g., Sorkin, 2009; Duchin and Sosyura, 2012). Thus, politically connected insiders at leading financial institutions were in a position to be disproportionately privately informed about the scope of government

\footnotetext{
${ }^{1}$ Throughout the paper we use the term "insider" or "corporate insider" to refer to officers and directors covered by Section 16(b) of the Securities and Exchange Act of 1934 which requires such insiders to disclose their trades on Form 4 filings with the Securities and Exchange Commission.
} 
intervention, how this intervention would affect their firms, and details of any forthcoming TARP monies.

While there are good reasons to suspect that politically connected insiders had private information in this setting, it is not obvious that insiders would trade based on this information. Opportunistic use of political connections for personal gain carries very significant risks. For example, unlike other market participants, corporate officers and directors owe a fiduciary duty to shareholders to "disclose or abstain (from trading)." If officers or directors had private information that their firm would receive government monies, their fiduciary duty compels them to either disclose that information or abstain from trading until such time as the information becomes public. In this regard, our tests are joint tests that political connections provide an information advantage and that insiders trade based on this advantage. We expect the formerthe opportunity for informed trading — to be more pronounced during the Crisis than during other periods.

We examine the relation between political connections and the trading of corporate insiders using a comprehensive sample of all open market purchases and sales of Section 16 officers and directors ("insiders") at 497 publicly traded financial institutions ("banks") between 2005 and 2011. Following prior research, we measure political connections based on whether a board member has current or previous work experience at the Federal Reserve, Treasury Department, Congress, or a bank regulator (e.g., Office of Comptroller of Currency (OCC), Office of Thrift Supervision (OTS), or Federal Deposit Insurance Corporation (FDIC)). We then measure the "informativeness" of insider trades based on their predictive ability for future performance. 
We begin our analysis by examining trades prior to the Crisis. Consistent with the notion that managers were unable to predict the effect of the forthcoming Crisis on their firm (e.g., Fahlenbrach and Stulz, 2011), we find no evidence that insider trades predict future performance over the 24 months leading up to the Crisis, or during the Crisis before the creation of TARP (i.e., prior to October 2008), and no evidence of a relation between political connections and informed trading during either period. In contrast, over the nine months after the creation of TARP (i.e., the period in which TARP funds were disbursed), we find a sharp increase in the predictive ability of insider trades for future performance. Consistent with the sharp increase in relating to private information gleaned from political connections, we find that the increase is concentrated almost entirely in the trades of politically connected insiders. During the period TARP funds were disbursed, the difference in one-month-ahead future returns between purchases and sales of insiders with (without) political connections is both economically and statistically significant, $8.89 \%(2.81 \%){ }^{2}$

These findings are robust to a battery of sensitivity analyses including using various fixed effect structures to control for firm-specific characteristics, changes in market conditions, and a differential effect of market conditions on firms with and without politically connected insiders. Our analysis suggests that within a given firm, those officers and directors with political connections outperform their peers during the Crisis. These results are consistent with political connections providing insiders with an information advantage and insiders opportunistically trading to exploit that advantage. The results suggest political connections are more likely to

\footnotetext{
${ }^{2}$ During this period there were 3,058 trades by politically connected insiders that amount to over $\$ 324$ million in trading volume. Average trade size was $\$ 105,987$ and the average trade earned market-adjusted profits of $\$ 22,251$; aggregating across all trades yields $\$ 68$ million in profits. Market-adjusted profits are calculated as the signed dollar value of the trade, multiplied by the market-adjusted buy-and-hold return over the subsequent 180-days (Ravina and Sapienza, 2010; Jagolinzer, Larcker, and Taylor, 2011).
} 
influence trading decisions during periods in which the government plays an active role in capital markets (i.e., during periods of large-scale government intervention).

While our findings suggest politically connected insiders had a significant information advantage during the Crisis and opportunistically traded to exploit this advantage, they do not speak to the source of this information advantage. We conjecture two potential sources. First, politically connected insiders might have been "tipped" about forthcoming TARP infusions. ${ }^{3}$ Second, even in the absence of a tip, politically connected insiders might be more skilled at forecasting government actions. In this regard, politically connected insiders would have an advantage over both politically connected outsiders and unconnected insiders. This is a subtle distinction. From an economic standpoint, both cases entail trading of private informationinformation that is not common knowledge and not impounded into price.

Admittedly, in the absence of directly observing the "tip," it is difficult to empirically discriminate between these two potential sources of private information. Indeed, this is a general limitation of prior academic research examining the trading patterns of corporate insiders- their trades are known to predict future performance, but it is difficult to pin down the source of the information or the channel through which insiders learn that information (e.g., Cohen, Malloy, Pomorski, 2012). Nonetheless, we conduct two additional sets of analyses to strengthen empirical identification and speak to potential sources of insiders' information advantage.

First, we use detailed data on officers' and directors' work history disclosed in proxy statement biographies to construct a partial network map. While undoubtedly incomplete, this

\footnotetext{
${ }^{3}$ This is consistent with prior research that suggests social connections generally, and political connections specifically, serve as a conduit for information transfer (e.g., Cohen, Frazzini, and Malloy, 2008, 2010; Gao and Huang, 2016; Ahern, 2017; Christensen, Mikhail, Walther, and Wellman, 2017). It is also consistent with prosecuted cases of information leakage by politically connected individuals. For anecdotes, see Hamburger (2013); Henning (2013); McCoy (2014); Viswanatha, Davidson, Mullins, and Matthews (2015); Mullins and Viswanatha (2016); and Cox (2017).
} 
map enables us to trace the nature of the political connection, the degrees of separation, the recency of the connection, and identify several relevant individual traits. We then correlate these connection attributes with the informativeness of insider trades during the Crisis. Within the sample of politically connected insiders who trade during the Crisis, we find that the information advantage is most pronounced among insiders with recent, direct connections.

Second, we examine insider trades thirty days prior to TARP infusions. Measuring trading by corporate insiders over the thirty days prior to the announcement of their firm's TARP infusion, we find that insiders are net buyers (sellers) before 34.8\% (20.3\%) of infusions in our sample. We find a pronounced increase in trading activity of politically connected insiders 30 days prior to the announcement, and that these trades predict the market reaction to the infusion. Notably, similar results are not observed among insiders without political connections; insiders without political connections do not appear to time their trades to coincide with TARP infusions. Evidence of abnormal trading activity among politically connected insiders thirty days prior to the TARP infusion would suggest insiders are trading based on superior information about TARP infusions.

The staggered nature of TARP infusions provides several potential avenues to control for confounding effects, and the results are robust to a variety of sensitivity tests. For example, similar results are not observed among politically connected insiders on non-announcement dates, among politically connected insiders around other corporate events that are not directly related to TARP infusions (e.g., earnings announcements), or among politically connected insiders in firms that did not receive TARP funds. Taken together, the results of our event study suggest that TARP infusion were front-run by politically connected insiders. 
Finally, to help isolate a potential source of information, we obtain data on TARP applications through a Freedom of Information Act (FOIA) request to the US Treasury. While Treasury did not furnish the actual TARP application or dates of associated correspondence, they did provide us with a list of bank names, application dates, and application amounts. ${ }^{4}$ We find trades of political connected insiders that "front run" the infusion vary with the wedge between the infusion amount and application amount. The greater the infusion as a percentage of the application, the more likely politically connected insiders were to purchase shares 30-days prior to the infusion. Similar results are not observed among insiders without connections. These results suggest that private information about TARP infusions is one potential source (but not necessarily the exclusive source) of politically connected insiders' information advantage.

Overall, our findings suggest that political connections provided corporate insiders with an important information advantage during the Financial Crisis and that insiders traded to exploit their advantage. This conclusion is subject to two important caveats. First, from correlations alone, it is difficult to speak to the legality of a given trade or series of trades. This limitation is not unique to our study and applies broadly to the academic literature on insider trading and option backdating (see Ritter, 2008). Nevertheless, our analysis casts suspicion on trades of politically connected insiders during the Crisis, especially those trades that occurred in close proximity to TARP infusions. At a minimum, the behavior we document is evidence of opportunism on the part of politically connected insiders. Uncovering such opportunism furthers our understanding of the consequences of opacity in government decision-making, and illustrates a novel channel through which insiders could benefit from crony capitalism.

\footnotetext{
${ }^{4}$ The raw data is provided in Table IA.VIII of the Internet Appendix.
} 
Second, our focus on financial institutions during the Crisis potentially limits the generalizability of our findings — our findings do not generalize to the "average politically connected insider" or "average period." However, generalizability is less of a concern given our research question. We do not seek to examine whether the average politically connected insider trades opportunistically, but rather whether a detectable set of politically connected insiders engage in such behavior when given the opportunity. Our findings are particularly salient in the current economic climate, where the government is playing a more active role in U.S. capital markets. As the government becomes more active in influencing firm-level outcomes, we expect politically connected insiders to be at an information advantage and encourage investors and market regulators to monitor the trades of politically connected insiders.

The remainder of the paper proceeds as follows. Section I discusses related prior literature and the institutional setting. Section II describes our sample and measurement of key variables. Section III presents results from our primary regression tests. Section IV discusses the construction and analysis of the map of insiders' networks. Section V presents our event study tests relating to TARP infusions. Section VI discusses several alternative explanations, robustness tests, and additional analyses. Section VII provides concluding remarks.

\section{Related Literature}

Our study bridges three distinct literatures: government intervention during the Financial Crisis, political connections, and insider trading.

\section{A. Government Intervention During the Financial Crisis}

On September 18, 2008, congressional leaders met with Treasury Secretary Henry Paulson and Chairman Ben S. Bernanke and were briefed on a plan for massive government 
intervention in the financial system on a scale not seen since the Great Depression (Appelbaum and Montgomery, 2008). On September 22nd, a draft TARP bill (the Emergency Economic Stabilization Act of 2008) was circulated on Capitol Hill. The bill was eventually defeated in the House of Representatives on September 29th over concerns about inadequate transparency and the staggering size of funds requested (Hulse and Herszenhorn, 2008). A few days later, on October 1st, the Senate considered and passed a revised TARP bill, which was subsequently passed by the House of Representatives and signed into law by the President on October 3rd. As part of TARP-implementation, in mid-October 2008, the Treasury Department announced its intent to use TARP funds to purchase $\$ 250$ billion in equity in the form of preferred stock from a broad array of financial institutions. While participation for the nine largest banks was mandatory, subsequent participation was voluntary. ${ }^{5}$ Prior research generally suggests these "TARP infusions" resulted in significant changes in firm value. For example, Veronesi and Zingales (2010, p. 340) estimate that TARP “created between $\$ 86$ and $\$ 108$ billion in value." Importantly, prior research also suggests a considerable "political dimension" to the creation and allocation of TARP funds. Mian, Sufi, and Trebbi (2010) find that finance industry campaign contributions were associated with politicians' votes on the bill that created TARP; Duchin and Sosyura (2012) find that political connections influenced the probability that a bank received TARP funds; and Tahoun and Van Lent (2013) show that the financial interests of

\footnotetext{
${ }^{5}$ The nine banks initially receiving TARP were "forced" to take the infusion in order to mitigate concerns about adverse selection with respect to funding (e.g., Landler and Dash, 2008). These banks include: Bank of America, Bank of New York Mellon, Citigroup, Goldman Sachs, JP Morgan, Merrill Lynch, Morgan Stanley, State Street, and Wells Fargo. A total of 707 financial institutions received injections: 350 were publicly traded banks, 296 were private banks, 57 were thrifts, and 4 were non-bank financial institutions. Ultimately, TARP provided approximately $\$ 205$ billion in capital infusions and was effectively concluded by June 2009 .

${ }^{6}$ Bayazitova and Shivdasani (2012) document returns of approximately $15 \%$ for the October 14 th announcement date for the initial nine recipients and approximately $4 \%$ for subsequent recipients (see also, Farruggio, Michalak, and Uhde, 2013). Ng, Vasvari, and Wittenberg-Moerman (2011) report that after the conclusion of the program, the portfolio of recipients outperformed non-recipients by $10.3 \%$ through December 2010.
} 
ranking members of finance-related Congressional subcommittees influenced the provision of TARP funds. The unprecedented magnitude of government intervention during the Financial Crisis and its political nature provide a powerful setting to examine whether political connections facilitate opportunistic behavior.

\section{B. Political Connections}

A large literature suggests that political connections facilitate access to capital (e.g., Khwaja and Mian, 2005; Faccio, Masulis, and McConnel, 2006; Leuz and Oberholzer, 2006; Claessens, Feijen, and Laeven, 2008), can be instrumental in winning government procurement contracts (e.g., Goldman, Rocholl, and So, 2013; Tahoun, 2014), and can favorably influence tax policy (e.g., Brown, Drake, and Wellman, 2015). Studies in this literature generally conclude that political connections are value-increasing (e.g., Goldman, Rocholl, and So, 2009; Cooper, Gulen, and Ovtchinnikov, 2010). For example, within the context of the Crisis, Acemoglu et al. (2016) report that financial institutions connected to Timothy Geithner experienced an abnormal return of $6 \%$ on the day he was announced as nominee for Treasury Secretary.

Valuation implications notwithstanding, there is scant evidence on whether insiders' political connections facilitate opportunistic behavior. For example, several recent studies examine the relation between political connections and prosecutions for white-collar crime (e.g., Yu and Yu, 2011; Correia, 2014; Bourveau, Coulomb, and Sangnier, 2018). We contribute to this literature by examining opportunistic use of political connections, and by documenting that such connections facilitate one particular form of opportunism — informed trading. Broadly speaking, the notion that political connections might facilitate informed trading is in line with prior work that suggests politicians are able to use their privilege information to earn abnormal returns themselves (e.g., Ziobrowski, Cheng, Boyd, and Ziobrowski, 2004). 


\section{Insider Trading Literature}

It is illegal for insiders to trade while in possession of material non-public information (Securities and Exchange Acts of 1933 and 1934; Insider Trading Sanctions Act of 1984; Insider Trading and Securities Fraud Enforcement Act of 1988). Moreover, unlike other market participants, corporate officers and directors owe a fiduciary duty to shareholders, a duty that requires them to "disclose or abstain (from trading)." Thus, while there are strong reasons to suspect that politically connected insiders were at an information advantage during the Crisisand thus had the opportunity to trade — it is not obvious that insiders would exploit this advantage.

Prior research finds mixed evidence that insiders traded in anticipation of the Crisis. On the one hand, Bebchuk, Cohen, and Spamann (2010) report that top executives at Bear Stearns and Lehman Brothers "cashed out" \$1 billion in performance-based compensation between 2000 and 2008, and Bhagat and Bolton (2014) report that over the same period the dollar value of insider sales at the fourteen largest banks was 100 times the dollar value of insider purchases. Similarly, Ryan, Tucker, and Zhou (2016) find that insider sales prior to the Crisis predict writedowns on securitized loans during the Crisis. On the other hand, Fahlenbrach and Stulz (2011) report that the CEOs at the top eighty banks did not significantly reduce their ownership between 2007 and 2008 and Cheng, Raina, and Xiong (2013) find that managers of financial institutions aggressively increased their personal investments in the housing market leading up to the Crisis.

This is the first paper to examine whether politically connected insiders traded to exploit their information advantage during the Crisis. Similar to our analysis-in a subsequent working paper-Akin, Coleman, Fons-Rosen, and Peydro (2018, ACFP) examine whether the cumulative trades of politically connected insiders during the Crisis predicts the market reaction to TARP 
infusions. While this finding is similar in spirit to one aspect of our analysis, ACFP do not examine trades in short windows (i.e., 1-month or less) before TARP infusions, do not conduct a broad panel data analysis of the relation between political connections and informed trading pre-, during-, and post- Crisis, and do not build a partial network map of political connections to analyze individual attributes of the connection.

Our paper extends this literature by offering novel evidence on the relation between political connections and informed trading pre-, during, and post- Crisis. While prior literature finds insiders' trades reflect private information, identifying the source of insiders' information advantage is challenging. Our findings suggest insiders' political connections are one potential source of private information and this information is being shared within the firm: political connections provide an information advantage which is partially (but incompletely) transferred to other board members at the firm.

\section{Data and Measurement}

\section{A. Sample}

We collect data on officer and directors trades from the Thomson Reuters Insider Filings (Form 4) database. This database contains detailed information on the trades of corporate insiders in their firm's equity. ${ }^{7}$ Consistent with prior work, we restrict our analyses to open market purchases and sales of common equity and exclude option exercises, option grants, and gifts. We require the trade price, the number of shares transacted, and the date of the transaction for each trade. We restrict attention to trades by individuals classified as a Section 16 officer or

\footnotetext{
${ }^{7}$ We do not observe officers and directors trades in other firms or trades of low level employees.
} 
director at a publicly traded financial institution and aggregate insider trades to the insider-month level.

The Crisis is generally thought to have started in July 2007 and concluded two years later, in June 2009. Accordingly, we restrict attention to insider trades between July 2005 and June 2011, inclusive. This provides a symmetric two year window both before and after the Crisis, and ensures all trades in our sample occur after the effective date of the Sarbanes-Oxley Act of 2002, which required corporate insiders to report their trades electronically to the SEC within two business days. We refer to the two year period, July 2005 to June 2007, as the "PreCrisis period," the two year period, July 2007 to June 2009, as the "Crisis period," and the two year period, July 2009 to June 2011, as the "Post-Crisis period." We further divide the Crisis period into two periods: the "Pre-Bailout period" from July 2007 to September 2008, and the "Bailout period" from October 2008 to June 2009 — the months in which 99\% of TARP funds were disbursed. ${ }^{8}$

We merge the Thomson Reuters Insider Filings database with CRSP/Compustat to obtain data on stock returns, market value, book-to-market ratios, and earnings. To appear in the sample, we require market value at the end of the month, non-missing returns in the prior month $(t-1)$ and prior year ( $t-2$ to $t-12)$, and book value of equity at the end of the prior fiscal quarter. Finally, we require data on insiders' political connections. Our measure of political connections is taken from Duchin and Sosyura (2012), and covers all publicly traded financial institutions that were eligible for TARP funds (i.e., domestically controlled banks, bank holding companies,

\footnotetext{
${ }^{8}$ NBER business cycle dates indicate that a recession starts in the fourth quarter of 2007 and continues through the end of the second quarter of 2009, but prior work generally considers the crisis to start at the beginning of the third quarter of 2007 (e.g., Acharya and Richardson, 2009; Brunnermeier, 2009; Fahlenbrach and Stulz, 2011). Inferences throughout the paper are robust, and are generally strengthened, if we define the Crisis as ending in March 2009 or December 2009, rather than June 2009. Figures 2 and 3 present results in six month intervals from 2005 through 2011 and provide a sense of the robustness of our results to the definitions of various sample periods.
} 
and saving and loan associations). After requiring data on political connections, the final sample for our cross-sectional tests consists of trades by 7,301 corporate insiders at 497 firms from July 2005 to June 2011 , for a total of 29,777 insider-months.

\section{B. Measure of Political Connections}

Following Duchin and Sosyura (2012), we measure political connections based on whether the bank's board includes at least one member with current or previous work experience at the Federal Reserve, a bank regulator (such as the Federal Deposit Insurance Corporation (FDIC), Office of Thrift Supervision (OTS), or Office of the Comptroller of the Currency (OCC)), Treasury, or Congress. Work experience is determined by analyzing each director's biographical data as provided in the BoardEx database and the firm's proxy statements. All officer and directors at banks in which one or more members of the board list such work experience are deemed "politically connected insiders."9

In the context of our research question, this measure of political connections has two desirable properties. First, unlike other measures such as campaign contributions or lobbying expenditures, work experience allows us to detect direct connections to bank regulators- $\mathrm{a}$ connection that would be more difficult to infer from contributions to political campaigns. Second, our measure focuses broadly on whether an insider's close professional network within the firm (i.e., the board of directors) contains someone with direct political or regulatory ties rather than focusing narrowly on the individual with the tie. Anecdotal and empirical evidence suggests that there is significant sharing of private information among board members (e.g., Cao, Dhaliwal, Li, and Yang, 2015; Kim, 2016), and an analysis of prosecuted cases suggests that trading on private information typically occurs more than one degree of separation from the

\footnotetext{
${ }^{9}$ We thank Ran Duchin and Denis Sosyura for providing these data.
} 
source of private information (e.g., Ahern, 2017). It seems plausible that private information would be shared either formally or informally within the firm's board of directors during the Crisis (see the first-hand accounts detailed in Sorkin, 2009). Hence, we include a broad set of corporate insiders who interact professionally (and likely socially) on a routine basis. If anything, misclassifying individuals as connected when no such connection exists, biases against finding a relation between connections and their trades. In subsequent analysis, we focus on specific individuals with connections and the attributes of the connection (e.g., recency of the connection, degrees of separation, etc).

\section{Descriptive statistics}

Table I presents descriptive statistics for our sample. Panel A suggests that the typical firm in our sample has a market capitalization of roughly $\$ 250$ million (mean natural logarithm of market value, Size, of 5.59), a book-to-market ratio of about 1.02, and negative returns in both the prior month (mean PastMoRet of -1.78\%) and the prior year (mean PastYrRet of $-5.11 \%$ ). Panel A also suggests that the Board of the average firm in our sample has 0.58 directors with political connections (mean NumPolConn of 0.58 ); that $34 \%$ of firms have at least one director with political connections (mean Connected of 0.34); and that slightly more than half of the sample received TARP funds (mean TARPRecipient of 0.56). ${ }^{10}$

Panel B suggests that the majority of all trades in the sample are net purchases (mean Buyer of 0.68); and that the total dollar volume of insider purchases (sales) is just over $\$ 1.5$ billion (\$6.1 billion). The observation that the dollar value of insider sales is so much larger than

\footnotetext{
${ }^{10} \mathrm{We}$ winsorize all continuous variables at the 1st and 99th percentiles and exclude all insider trades (aggregated by month) of $\$ 100$ million or more. This results in the exclusion of 11 transactions: a $\$ 737$ million dollar open market sale by Citigroup director Roberto Hernandez Ramirez on November 9, 2006 (shares were acquired in connection with Citigroup's purchase of Banamex), a \$288 million dollar open market sale by a Etrade director Kenneth Griffin on April 29, 2010 (in his capacity as CEO of Citadel LLC), and nine purchases of \$100 million or more in connection with MatlinPatterson Global Advisers' investment in FlagStar bank in January, March, and November of 2010. All of these 11 transaction occurred outside the Crisis period, and thus do not affect our inferences.
} 
that of purchases is consistent with prior research on insider trading outside the context of the Crisis (e.g., Ravina and Sapienza, 2010). Thus, while the number of purchase transactions is greater than the number of sales transactions, the dollar volume of sales is substantially larger.

Panel B also reports descriptive statistics after partitioning the sample based on insiders' political connections. There are 2,767 (4,534) distinct insiders with (without) political connections in our sample at 159 (338) distinct firms. Panel B reports that 54\% (74\%) of trades by insiders with (without) political connections are net purchases; the total value of purchases by insiders with (without) political connections is $\$ 769$ million (\$793 million); and the total value of sales by insiders with (without) political connections is $\$ 4.5$ billion ( $\$ 1.6$ billion). These statistics suggest insiders with political connections are both more likely to sell shares, and sell shares in greater volume.

\section{Insider Trading During the Crisis}

Figure 1 plots the total dollar value of insider purchases and sales over time. Figure 1 suggests the dollar volume of insider sales dropped dramatically at the start of the Crisis, whereas the dollar volume of insider purchases increases at the start of the Crisis and is the highest during the Bailout period.

[INSERT FIGURE 1 ABOUT HERE]

Table II presents average values of our measures of insider trading activity in each period. Panel A suggests that 55\% of trades are buys prior to the Crisis, $76 \%$ during the PreBailout period, and 78\% during the Bailout period. Panel B of Table II presents average values for our measures of insider trading activity after partitioning the sample based on insiders' political connections. Panel B suggests that insiders with political connections tend to be net sellers before the Crisis (39\% of trades in the Pre-Crisis period are purchases), net buyers during 
the Crisis (68\% of trades in the Crisis period are purchases), and that their buying is most intense in the Bailout period ( $74 \%$ of trades in the Bailout period are purchases). Panel B also suggests that, while insiders with political connections tend to purchase less frequently than insiders without political connections (mean Buyers of 0.54 and 0.74 respectively), the difference in buying activity narrows significantly during the Bailout period (mean Buyers of 0.74 and 0.80 respectively). Insiders with political connections typically account for around $73 \%$ of sales volume, and their share of sales volume decreases sharply to $43 \%$ during the Bailout period. Conversely, insiders with political connections typically account for around $49 \%$ of purchase volume, and their share of purchase volume increases sharply to $71 \%$ during the Bailout period.

The evidence in Figure 1 and Table II suggests a relative increase in buying among insiders with political connections during the Crisis. The percentage of trades (dollar volume) that are purchases increases during the Bailout period, and this increase appears concentrated among insiders with political connections. However, there is significant cross-sectional variation in insider trading activity within each period. This within-period variation is the basis for our subsequent tests regarding the predictive ability of insider trades for the cross-section of future performance.

\section{Predictive Ability of Insider Trades for Future Performance}

\section{A. Difference in Future Returns between Purchases and Sales}

The evidence thus far speaks to patterns in the trading behavior of corporate insiders, but does not speak to the extent to which those trades are informed, i.e., anticipate future performance. Our primary tests examine the informativeness of insider trades, and how it relates to political connections. Following a large insider trading literature, we measure the 
informativeness of insider trades based on the predictive ability of the trades for future returns. If trades are based on private information, future returns should be higher (lower) among firms where insiders buy (sell) (e.g., Aboody and Lev, 2000; Lakonishok and Lee, 2001; Jeng, Metrick, and Zeckhauser, 2003; Cohen, Malloy, and Pomorski, 2012). In this regard, we measure insiders' information advantage relative to the information already impounded in prices.

Panel A of Table III presents average one-month-ahead future returns separately following purchases and sales. Consistent with findings in prior literature, we find the direction of insider trades is associated with the sign of subsequent stock returns. Over the full sample period, purchases foreshadow positive future returns $(0.23 \%)$ and sales foreshadow negative future returns $(-0.82 \%)$. Consistent with prior work, the difference in returns following purchases and sales is both economically and statistically significant, $1.05 \%$ per month over the entire sample ( $t$-stat. of 6.76). Panel A of Table III also reveals that the predictive ability of insider trades for future performance is greater during the Bailout period than any other period in our sample. Both the predictive ability of insider purchases for positive future performance and the predictive ability of insider sales for negative future performance increase during this period. The average one-month-ahead future return following purchases (sales) is $1.84 \%(-2.87 \%)$, a difference of $4.71 \%$.

Panel B of Table III presents results after partitioning the sample based on insiders' political connections. Panel B reveals that the difference in one month ahead returns between purchases and sales during the Bailout period is $8.89 \%$ (2.81\%) for insiders with (without) political connections - larger than during any other period in the sample. The difference in these differences, $6.08 \%$, is both economically and statistically significant ( $t$-stat of 3.81). Notably, in all periods except the Bailout period, the difference in returns between purchases and sales 
appears unrelated to insiders' political connections (difference-in-differences $t$-stats of -1.50 , 0.89, and -0.10 during the Pre-Crisis, Pre-Bailout, and Post-Crisis periods, respectively).

Figure 2 plots the difference in one-month-ahead future returns between purchases and sales over time. Figure 2 suggests the difference in future returns is negligible prior to the Crisis, is increasing as the Crisis unfolds, and remains elevated until the end of 2010. This suggests the findings are not sensitive to lengthening the definition of the Crisis period to include all of 2009.

\section{[INSERT FIGURE 2 ABOUT HERE]}

Figure 3 plots the difference in one-month-ahead future returns between purchases and sales separately for insiders with and without political connections. Figure 3 shows a dramatic spike in the predictive ability of politically connected insiders' trades for future returns during the period in which TARP funds were distributed. We next test whether the univariate patterns in future returns following insider trades are robust to: (i) controlling for cross-sectional determinants of returns, (ii) measuring returns over longer horizons, (iii) conducting a withinfirm analysis, (iii) controlling for contemporaneous changes in market conditions, and (iv) controlling for differences in market conditions between firms with and without politically connected insiders.

\section{[INSERT FIGURE 3 ABOUT HERE]}

\section{B. Pooled Regression Tests}

Following Cohen, Malloy, and Pomorski (2012) we estimate regressions of the form:

$$
\text { BHR }_{t+s}=\delta_{1} \text { Buyer }_{t}+\theta \text { Controls }_{t}+\varepsilon_{t+1}
$$

where $B H R_{t+s}$ is either returns over the next month $(s=1)$ or over the next six months $(s=6)$. Measuring returns over the future six-months allows for the possibility that it takes longer than one month for insiders' private information to be impounded in prices. Buyer $t_{t}$ is an indicator 
variable equal to one if the number of shares bought by insider $i$ in firm $j$ in month $t$ exceeds the number of shares sold by insider $i$ in firm $j$ in month $t$, where all trades are aggregated to the insider-firm-month level. Controls $s_{t}$ is the vector of control variables that includes firm size $\left(\right.$ Size $\left._{t}\right)$, the book-to-market ratio $\left(B M_{t}\right)$, returns in the past month (PastMoRet $)$, and returns in the past year (PastYrRet $)$, For parsimony, we omit subscripts for insider $i$ at firm $j .{ }^{11}$ All variables are defined in Table I. In this specification, $\delta_{1}$ represent the difference in future returns between buys and sells, after controlling for size, book-to-market, and past returns.

To examine whether the predictive ability of insider trading activity increases during the Crisis, before or after government intervention, we include separate indicator variables,

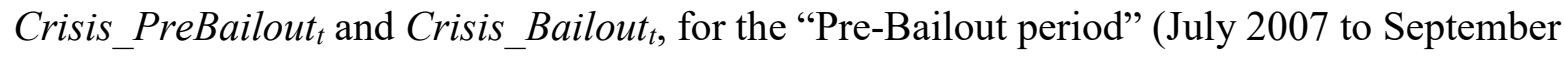
2008) and the Bailout period (October 2008 to June 2009), and interact these variables with Buyert.

$$
\begin{aligned}
\text { BHR }_{t+s}= & \delta_{1} \text { Buyer }_{t}+\delta_{2} \text { Buyer }_{t} * \text { Crisis_PreBailout }_{t}+\delta_{3} \text { Buyer }_{t} * \text { Crisis_Bailout }_{t} \\
& +\beta_{1} \text { Crisis_PreBailout }_{t}+\beta_{2} \text { Crisis_Bailout }_{t}+\theta \text { Controls }_{t}+\varepsilon_{t+1},
\end{aligned}
$$

In this specification, $\delta_{2}$ and $\delta_{3}$ measure the incremental informativeness of insider trades during the Crisis, prior to and following government intervention, respectively. Throughout our analysis we base inferences on standard errors clustered by firm. Clustering by firm allows for both arbitrary time-series correlation within a firm and arbitrary cross-sectional correlation across insiders within a given firm.

Table IV reports results from estimating equations (1) and (2). Panel A presents results from measuring future returns at the one month horizon. On average, across the entire sample period, results in columns (1) suggest insider trades are related to future returns (Buyer, $t$-stat of

\footnotetext{
${ }^{11}$ We find there are only 21 insiders who overlap across multiple firms in our sample, and thus the unit of analysis is effectively an insider-month.
} 
2.04). Column (2) allows the relation between insider trades and future returns to vary over time. We find no evidence of a change in the informativeness of insider trades during the Crisis prior to the creation of TARP (Buyer*Crisis_PreBailout $t$-stat of -0.07), and a marked increase in the informativeness of insider trades during the Crisis following the creation of TARP (Buyer*Crisis_Bailout $t$-stat of 2.49).

To examine the relation between political connections and the informativeness of insider trades, we estimate equation (2) separately for the sample of insiders with political connections $($ Connected $=1)$ and without political connections $($ Connected $=0)$. Column $(3)$ presents results for the sample of insiders with political connections, column (4) presents results for the sample of insiders without political connections, and column (5) tests for differences in coefficients between the two samples.

Interestingly, the coefficient on Buyer*Crisis_Bailout is economically and statistically significant only for the trades of politically connected insiders. Column (3) suggests that among the trades of politically connected insiders, the difference in one-month returns between purchases and sales increases from an economically and statistically insignificant $-0.20 \%$ in the non-Crisis period to $6.23 \%$ during the Bailout period (a difference of $6.43 \%, t$-stat of 3.35). Additionally, column (5) suggests that the coefficient on Buyer*Crisis_Bailout estimated on the sample of insiders with political connections, is economically and statistically larger than the same coefficient estimated on the sample of insiders without political connections (difference of 5.80, $p$-value $<0.01)$.

Notably the difference in informativeness of insider trades between insiders with and without political connection is unique to the Bailout period: the difference in the coefficients on Buyer and the difference in the coefficients on Buyer*Crisis_PreBailout are not statistically 
significant ( $p$-values of 0.15 and 0.85 respectively). We also note that the differences in the coefficients on the control variables are generally not statistically significant, which suggests that the determinants of the cross-section of returns do not vary with insiders' political connections.

Panel B of Table IV presents similar results measuring future returns over the six month horizon. Column (5) of Panel B suggests that the coefficient on Buyer*Crisis_Bailout estimated on the sample of trades by insiders with political connections, is economically and statistically larger than the same coefficient estimated on the sample of trades by insiders without political connections (difference of $20.17, p$-value $<0.01$ ).

Table $\mathrm{V}$ reports results after including firm and date fixed effects in the prior specification. This fixed effect structure is an important feature of our design. First, in the presence of firm-level fixed effects, our design relies on within-firm variation. As such, the inclusion of firm-fixed effects helps mitigate concerns about omitted firm-level characteristics that might be correlated with future performance, insider trading activity, and political connections. Our firm fixed effects control for any time-invariant, cross-sectional differences between firms with and without political connections (e.g., corporate governance, pre-Crisis exposure to housing market). Second, date-level fixed effects control for changes in market conditions that affect all firms within a given period. We include separate date fixed effects in each sample of insider trades. By doing so, we explicitly account for the possibility of different time period effects (and different time trends) between the two samples. Including separate date fixed effects in each sample allows for the possibility that market conditions might differentially affect firms with and without politically connected insiders. Date fixed effects subsume the timeperiod indicator variables Crisis_PreBailout and Crisis_Bailout. 
Columns (1) through (3) of Table V present results from including firm fixed effects. Columns (4) through (6) present results from including date fixed effects. Columns (7) through (9) present results from including firm and date fixed effects. For parsimony, coefficients on control variables are not tabulated. The results in Table V suggest that our inferences are robust to these alternative fixed effect designs. We continue to find strong evidence of an increase in the informativeness of insider trades during the Bailout period, and only among politically connected insiders. This suggests our results are not driven by temporal changes in market conditions, a differential effect of market conditions on firms with and without politically connected insiders, or time-invariant characteristics of the firm. To explain our results, an omitted variable would need to explain not only why—within a given firm—-buys (sells) are followed by positive (negative) returns, but also why the difference in returns following buys and sells increases during the Bailout period, and why the increase is concentrated among the trades of insiders with political connection. ${ }^{12}$

While the results suggest politically connected insiders had a significant information advantage during the Crisis and opportunistically traded to exploit this advantage, they do not speak to the source of this information advantage. Next, we conduct two additional sets of analyses to strengthen empirical identification and speak to potential sources of insiders' information advantage. First, we use detailed data on officers' and directors' work history disclosed in proxy statement biographies to construct a partial network map. While undoubtedly

\footnotetext{
12 Tables IA.I and IA.II of the Internet Appendix show inferences are unchanged if we replace Buyer with three alternative measures of insider trading activity (e.g., Lakonishok and Lee, 2001; Piotroski and Roulstone, 2005): (i) the purchase ratio, defined as the number of shares purchased scaled by number of shares purchased plus the number of shares sold; (ii) the net purchase ratio, defined as the dollar value of net purchases (purchases less sales) scaled by dollar volume of purchases plus the dollar value of sales, and (iii) the dollar value of net purchases. Table IA.III shows inferences are unchanged when using the algorithm in Cohen, Malloy, and Pomorski (2012) to classify traders as "opportunistic" and "routine" and focusing on opportunistic traders. Table IA.IV shows inferences are robust to aggregating insider-month observations to the firm-month level, and also to disaggregating insider-month observations to the individual transaction level.
} 
incomplete, this map enables us to trace the nature of the political connection, the degrees of separation, the recency of the connection, and identify several relevant individual attributes. We then correlate attributes of the connection and individual with the informativeness of their trades during the Crisis. Second, we implement an event study to examine whether insiders front-run TARP infusion announcements. Evidence of elevated trading among politically connected insiders in a short window prior to the TARP infusion, and that these trades anticipate the market reaction to the infusion, would suggest politically connected insiders are trading based on superior information about TARP infusions.

\section{Network Map and Attributes of the Connection}

Our primary tests use data on firm-level political connections collected by Duchin and Sosyura (2012). A key assumption of a firm-level measure of political connections is that privileged information is shared among board members. While this assumption is consistent with anecdotal and empirical evidence (e.g., Sorkin, 2009; Cao, Dhaliwal, Li, and Yang, 2014; Kim, 2016) information sharing among board members is difficult to verify in the absence of direct observation. In this section, we deviate from Duchin and Sosyura (2012) and measure political connections at the individual level. Specifically, we use the BoardEx database to construct a (partial) network map between government regulatory agencies and individual officers and directors. This network map allows us to (i) distinguish individuals with direct connections to government agencies from individuals who are connected "through" another insider's connection (i.e., an indirect connection), and (ii) distinguish individuals with recent connections from individuals with stale connections. Figure 4 provides an example.

[INSERT FIGURE 4 ABOUT HERE] 
To drill down on individual insiders, and individual connections, we conduct this analysis within the sample of firms with politically connected insiders who traded during the Bailout period (i.e., those observations for which Connected $=1$ and Crisis_Bailout $=1$ ). Panel A of Table VI presents the number of individuals in the sample with various attributes. Panel A shows that there are 740 individuals in this sample, of which 319 are officers $($ Officer $=1)$ and 138 are financial experts according to the definition provided in the Sarbanes-Oxley Act of 2002 (Financial Expert $=1$ ). Notably, 72 of the 740 are directly connected through current or prior work experience at the Federal Reserve, Treasury, Congress, or a bank regulator (i.e., OCC, OTS, or FDIC) at the time of the Crisis (Direct Connection $=1$ ) and the remaining 668 are connected through such individuals, i.e., sit on the same boards (Direct Connection $=0$ ).

Focusing on the 72 directly connected individuals, we identify the end date of the work experience. We use the end date of the work experience relative to 2008 as a rough proxy for the recency of the connection. For example, if a director stepped down from the Federal Reserve Board in 2005 , Recency $=3$. If the work experience continues through 2008 , the connection is considered current, and Recency is coded as zero. ${ }^{13}$ We consider a connection "recent" (Recent Direct Connection =1) if Recency $\leq 3$ and "stale" (Stale Direct Connection =1) if Recency $>3$. Panel A shows that 20 of the 72 directly connected individuals have recent connections.

Next, we examine the overlap between connections and other attributes. Panel B shows that of the 72 directly connected individuals, 38 are officers and 17 satisfy the financial expertise requirements of SOX. We caution that, as we continue to drill down on specific attributes of the connection and individual, sample sizes become considerably smaller.

\footnotetext{
${ }^{13}$ There is no rule against board members of financial institutions simultaneously serving on a Federal Reserve board. For such individuals, Recency is coded as zero. In cases where an individual has multiple direct connections (e.g., to both Treasury and the Federal Reserve), we use the most recent connection to calculate Recency.
} 
To examine how these attributes manifest in informativeness of insider trades, within the sample of trades by politically connected insiders during the Bailout period (i.e., within the sample of observations where Connected $=1$ and Crisis_Bailout=1), we estimate

$$
\begin{aligned}
& \text { BHR }_{t+6}=\delta_{1} \text { Buyer }_{t}+\delta_{2} \text { Buyer }_{t} * \text { Recent Direct Connection } \\
&+ \delta_{3} \text { Buyer }_{t} * \text { Stale Direct Connection }+\delta_{4} \text { Buyer }_{t} * \text { Officer } \\
&+\delta_{5} \text { Buyer }_{t} * \text { Financial Expert }+\theta \text { Controls }_{t} \\
&+ \text { Firm Effects }+ \text { Date Effects }{ }_{t}+\varepsilon_{t+1}
\end{aligned}
$$

Recent Direct Connection, Recent Stale Connection, Officer, and Financial Expert, are characteristics of the insider defined above, and Controls is a vector of control variables that includes all of the main effects of the interaction terms in addition to the control variables from equation (2), Firm Effects is a vector of firm fixed effects, and Date Effects $t$ is a vector of date fixed effects.

This analysis is effectively the regression specification in Table V, augmented with variables that measure attributes of the connection and the insider, and estimated within the sample of trades by politically connected insiders during the Bailout period. Because all individuals in this sample have either a direct or indirect connection, this regression specification effectively compares the informativeness of trades of insiders with indirect connections (measured by $\delta_{1}$ ) to those of insiders with recent direct connections (measured by $\delta_{1}+\delta_{2}$ ) and those of insiders with stale direct connections (measured by $\delta_{1}+\delta_{3}$ ). $\delta_{2}$ represents the difference in the informativeness of trades between insiders with recent direct connections $(\mathrm{N}=20)$ and insiders with indirect connections $(\mathrm{N}=668)$, and $\delta_{3}$ represents the difference in the informativeness of trades between insiders with stale direct connections $(\mathrm{N}=52)$ and insiders with indirect connections $(\mathrm{N}=668)$. 
Panel C of Table VI presents results from estimating equation (3). Focusing on the results in column (5), the results suggest that recent direct connections have the most informed trades $\left(\delta_{1}+\delta_{2}=45.29\right)$, followed by direct stale connections $\left(\delta_{1}+\delta_{3}=13.20\right)$, followed by indirect connections $\left(\delta_{1}=8.64\right)$. The difference between trades of recent direct connections and those of indirect connection is statistically significant ( $\delta_{2}=36.64, t$-stat 3.08). Moreover, the difference between trades of recent direct connections and those of stale direct connections is also statistically significant $\left(\delta_{2}-\delta_{3}=32.09\right.$, two-tailed $p$-value $\left.<0.01\right)$. However, the difference between trades of stale direct connections and indirect connections is insignificant $\left(\delta_{3}=4.56, t\right.$ stat 0.83$)$.

In addition, results in Panel $\mathrm{C}$ suggest attributes of the connection appear more salient to determining the informativeness of trades than other insider attributes such as officer/director or whether the insider is a financial expert ( $t$-stats of -0.28 and 0.12 on Buyer*Officer and Buyer*Financial Expert respectively). Our findings suggest that the information advantage and associated opportunistic trading is most pronounced among insiders with recent, direct connections, and that this advantage is partially, but incompletely, transferred to other board members at the firm (those with "indirect" connections). Recall that our tests are joint tests of an information advantage and that insiders trade on this advantage. Consequently, an alternative interpretation is that insiders with indirect connections and insiders with direct connections have a similar information advantage, but that the latter group trade more aggressively. ${ }^{14}$

\footnotetext{
${ }^{14}$ Consistent with incomplete information transfer between insiders with recent direct connections and other insiders on the same board, Table IA.V of the Internet Appendix reports that the trades of insiders with recent direction (Recent Direct Connection $=1$, Connected $=1$ ) are more informative than the trades of connected insiders without direction connections (Recent Direct Connection $=0$, Connected $=1$ ), which in turn are more informative that the trades of unconnected insiders (Recent Direct Connection $=0$, Connected $=0$ ).
} 


\section{Political Connections and Potential Front-Running of TARP Infusions}

\section{A. Event Study}

We next use an event study to further sharpen identification and investigate whether political connections facilitate front-running of TARP capital infusions. Specifically, we analyze both the timing and information content of insider trades around the announcement of TARP infusions. We use the short-window market reaction to the announcement of TARP infusions as a proxy for the extent to which the infusion surprised the market. If insiders traded on private information about the infusion (information that was not priced by the market), then we expect to observe a relation between insider trades before the announcement and the short-window market reaction to the announcement.

For this analysis, we focus only on firms in our sample that received TARP capital infusions. We collect data on TARP infusions from U.S. Treasury Department TARP transaction reports. Among other details, TARP transaction reports contain the date the Treasury provided the capital infusion, the name of the institution receiving the infusion, and the amount of the infusion. After imposing the above data requirements and excluding the nine initial participants forced to take TARP funds, the resulting sample used in our event study tests consists of 256 capital infusions to 249 unique firms (“TARP recipients") across 31 different calendar dates. ${ }^{15}$ Our search of firm disclosures on Factiva and Lexis-Nexus suggests the vast majority of announcements occur within one trading day of the infusion. We refer to the first full trading day

\footnotetext{
${ }^{15}$ Our sample of TARP capital infusions excludes Bank of America, Bank of New York Mellon, Citigroup, Goldman Sachs, JP Morgan, Merrill Lynch, Morgan Stanley, State Street, and Wells Fargo, as these banks were "forced" to take the infusion (inclusion of these banks does not affect our results). Our sample is similar in size to prior research. For example, after imposing data requirements, Bayazitova and Shivdasani (2012) and Duchin and Sosyura (2012) examine a sample of 286 TARP recipients, Ng, Vasvari, and Wittenberg-Moerman (2011) examine a sample of 186 recipients, and Farruggio, Michalak, and Uhde (2013) examine a sample of 125 recipients.
} 
after the infusion as day 0 , and use a three-day window $[-1,+1]$ to measure the market reaction. We find this window encompasses $95 \%$ of announcements. ${ }^{16}$

Figure 5 presents aggregate dollar volume of trading by corporate insiders at TARP recipients over the 60 days prior to the announcement, and the 60 days after the announcement. Figure 5 shows a clear increase in volume 30-days prior to the announcement, and that this increase is concentrated entirely among insiders with political connections. For politically connected insiders, volume increases from $\$ 32$ million over the $[-60,-31]$ to $\$ 105$ million during the $[-30,-1]$ window, and then falls to $\$ 16$ million during the $[0,+30]$ window, and is similar to pre-TARP levels, \$26 million, during the $[+31,+60]$ window. This suggest an abnormal surge in trading by politically connected insiders immediately prior to the infusion.

\section{[INSERT FIGURE 5 ABOUT HERE]}

Panel A of Table VII presents descriptive statistics for variables used in our event study tests. Focusing on the thirty trading days prior to the announcement, i.e., the $[-30,-1]$ window, we find that insiders traded during this window in 55\% of infusions $(89+52 / 256)$, that a total of 383 unique insiders traded during this period, and that the total dollar volume of their trades was $\$ 118$ million. Panel A also shows that the amount of the average infusion is substantial. For the average firm in our sample, the infusion represents $42.48 \%(2.28 \%)$ of prior quarter market value (book value of assets).

Panel A also presents descriptive statistics separately for the sample of infusions where insiders at the firm are net buyers (shares bought exceeds shares sold) and net sellers (shares sold exceeds shares bought) over the $[-30,-1]$ window. We find that insiders are net buyers before $34.8 \%$ of infusions in our sample and net sellers before $20.3 \%$ of infusions in our sample.

\footnotetext{
${ }^{16}$ Section 114(a) of Emergency Economic Stabilization Act of 2008 stipulates that the Treasury must publicly disclose recipients within 48 hours of the infusion.
} 
Infusions where insiders are net buyers are a much larger percentage of prior quarter market value.

Panel B of Table VII presents descriptive statistics for each of the four groups of infusions. Panel B suggests that, for infusions where politically connected insiders were net buyers (sellers) over the prior thirty trading days, the average the three-day announcement period return is $4.39 \%(-5.13 \%)$. These results suggest that when politically connected insiders were net buyers (net sellers) in advance of the announcement, the subsequent announcement was a large positive (negative) surprise to the market. Similar results are not observed for insiders without political connections. This suggests politically connected insiders appear to front-run TARP infusions.

In terms of magnitudes of gains and losses, Panel B reports $\$ 55.31$ million in purchases by 87 politically connected insiders over the 30 days before TARP infusions. This suggests the average purchase is $\sim \$ 635,000$ per insider (the average sale is $\sim \$ 780,000$ per insider). Even if we assume political connections allow the insider to reap a generous additional $10 \%$ abnormal profit (or avoid $10 \%$ in losses) from front-running the infusion, the dollar value comes out to less than $\$ 100,000$. Gains (or foregone losses) of this magnitude are quite common among insider trading cases pursed by the SEC and Department of Justice. ${ }^{17}$

As an alternative to partitioning by trading behavior and examining the difference in announcement returns, Figure 6 partitions by the sign of the announcement return and examines the differences in trading behavior. Panel A shows the aggregate dollar value of net purchases over the $[-60,+60]$ window around those announcements with positive announcement period returns. Panel A shows a significant spike in buying among politically connected insiders that

\footnotetext{
${ }^{17}$ For example, several pending cases at the time of this paper include allegations of gains (or foregone losses) of less than $\$ 200,000$. See https://www.justice.gov/criminal-fraud/insider-trading-fraud for examples.
} 
anticipates positive announcement returns. Panel B shows the aggregate dollar value of net purchases over the $[-60,+60]$ window around those announcements with negative announcement period returns. Panel B shows politically connected insiders are selling in much higher volume over both the 30 and 60-day windows in anticipation of negative announcement period returns. In both cases, similar patterns are not observed among insiders without political connections. ${ }^{18}$

\section{[INSERT FIGURE 6 ABOUT HERE]}

To test the hypothesis that trades shortly before the infusion predicted the market reaction, we regress the three-day announcement period returns on control variables from equation (1) and an indicator for whether insiders at the firm were net buyers over the prior thirty trading days, i.e., Buyer $(-30,-1)$, and estimate this regression separately for trades of connected and unconnected insiders. Panel C of Table VII reports results. The coefficient on Buyer $(-30,-1)$ is positive and statistically significant only in the subsample of firms where insiders are politically connected (sample of 94 infusions, $t$-stat of 2.24). We find no evidence of a relation between insider trades and announcement period returns among the subsample of firms where insiders are not politically connected (sample of 162 infusions, $t$-stat of -0.95 ). ${ }^{19}$

The results from our event study analysis are consistent with politically connected insiders trading in anticipation of the infusion. They suggest not only that insiders timed their trades in relation to the infusion announcement, but that the information content of the trades is related to TARP infusions. This is difficult to reconcile with alternative explanations, and the

\footnotetext{
${ }^{18}$ The sample sizes for this analysis (i.e., the number of trades in the respective window) are presented in Figure IA. 1 of the Internet Appendix.

${ }^{19}$ Panel A of Table IA.VI of the Internet Appendix repeats the analysis in Panel C of Table 7 focusing on trading activity over the $[-60,-30]$ window. We find no evidence that trades over this alternative window predict announcement returns. Panel B of Table IA.VI of the Internet Appendix repeats the analysis in Panel C of Table 7 after decomposing the indicator variable for whether insiders at the firm where net buyers over the $[-30,-1]$ window into separate indicators for (i) whether insiders were net buyers over the $[-5,-1]$ window, Buyer $(-5,-1)$, and (ii) whether insiders were net buyers over the $[-30,-6]$ window, Buyer $(-30,-6)$. Only the coefficient on the latter is significant, suggesting that the trades that anticipate the infusion are placed more than five-days prior.
} 
strategic timing of these trades (relative to the infusion) cannot be easily explained by omitted variables. At the very least, the evidence strongly suggests that politically connected insiders opportunistically timed their trades to front-run the infusion. ${ }^{20}$ We next conduct a battery of sensitivity analyses to assess the robustness of our results.

\section{B. Event study: Falsification Tests}

The staggered nature of TARP infusions provides several potential avenues to control for confounding effects. To examine whether our event study results are an artifact of test misspecification, we employ two falsification tests. If our tests are well-specified, and the relation between insider trades and announcement period returns is due to insiders trading on private information in anticipation of TARP infusions, then we do not expect to observe similar results among TARP recipient on non-announcement dates (i.e., holding the firms fixed and altering the dates), and should not expect to observe similar results for non-recipients on the announcement dates (i.e., holding the dates fixed but altering the sample of firms).

Panel A of Table VIII presents results from holding the set of TARP recipients fixed, and estimating the regression specifications in Panel C of Table VII for the same firms on all nonannouncement dates from October 2008 to June 2009 (i.e., the Bailout period). We then test whether the difference in the estimated regression coefficient for insiders with and without political connections during the announcement period is different from that during the nonannouncement period. Comparing the results between announcement and non-announcement periods enables us to rule out the possibility that what we are documenting is a general

\footnotetext{
${ }^{20}$ While firms often use "trading blackout windows" to limit insider trading in the months before material corporate events like earnings announcements, these windows are created and enforced by the firm, not by the SEC (e.g., Bettis, Coles, and Lemmon, 2000; Jagolinzer, Larcker, and Taylor, 2011). Given the number of infusions with insider trades thirty days before the infusion and the volume of trade, it is clear that either blackout windows did not apply to TARP infusions or were not enforced at the majority of firms in our sample.
} 
phenomenon among firms that receive TARP funds, and not a specific effect related to the announcement of a TARP infusion.

Panel A of Table VIII reports a statistically significant relation between the trades of politically connected insiders and returns on non-announcement dates ( $t$-stats of 5.83 and 3.79 for the trades of insiders with and without political connections respectively). Given prior results that insider trades predict returns even in the absence of TARP infusions, finding evidence of a positive relation between insider trades and returns during non-announcement dates should not be surprising. The important result is that the relation between political connections and the informativeness of insider trades is statistically and economically much larger during the announcement dates than during the non-announcement dates (diff-in-diff $p$-value $=0.03$ ).

Panel B of Table VIII presents results from holding announcement dates fixed, and estimating the regression specifications in Panel C of Table VII for firms that did not receive TARP infusions. We then test whether the difference in the estimated regression coefficients between insiders with and without political connections on the announcement date is different from that of non-recipients on the announcement date. For firms that did not receive TARP, we find no evidence of a relation between political connections and the informativeness of insider trades. We find that the relation between political connections and the informativeness of insider trades is statistically and economically much larger for TARP recipients during the announcement than for non-recipients during the announcement (diff-in-diff $p$-value $=0.01$ ).

Next, we compare front-running of TARP infusions with that of other events not directly related to TARP infusions. Panel A of Table IX compares the predictive ability of insider trades 30 days before TARP infusions to that of insider trades 30 days before earnings announcements. To conduct this test, we begin with the sample of 249 firms in our sample that received TARP 
infusions. We then gather data on quarterly earnings announcements during the Crisis period for these firms, three-day returns centered on the announcement date, and our control variables. This results in a sample of 1,619 earnings announcements for TARP recipients during the Crisis. We then repeat our earlier tests in Panel C of Table VII, measuring insider trading over the thirty days prior to the earnings announcement. Panel A of Table IX shows that the predictive ability of politically connected insiders' trades for TARP infusion announcements vastly exceeds that for earnings announcements.

Next, we compare front-running of TARP infusions with that on extreme return days. To conduct this test, we begin with the sample of 249 firms in our sample that received TARP infusions. For each firm, we then select the day during the Crisis with the most extreme price change (i.e., the largest unsigned return). We then repeat our earlier tests in Panel C of Table VII, measuring insider trading over the thirty days prior to the extreme return. Panel B of Table IX shows that the predictive ability of politically connected insiders' trades for TARP infusion announcements vastly exceeds that for extreme return days.

Collectively, we interpret the results in Tables 8 and 9 as suggesting that the relations we document are not observed in the absence of the announcement of TARP infusions, and appear to be a unique feature of such events.

\section{Event study: FOIA Analysis}

One limitation of using the market reaction to infusion announcements to measure "surprise" is that it comingles both the wedge between anticipated and received funds, and the valuation consequences of those funds. To disentangle these two, and to help pin down a potential source of information, we obtain data on TARP applications through a Freedom of 
Information Act (FOIA) request to the US Treasury. Treasury provided us with a partially redacted list of bank names, application dates, and application amounts.

Using this FOIA data, we measure the gap between the infusion amount and the application amount, and drill down on those infusions where insiders traded in the 30-day window prior to the infusion (sample of 105 infusions with requisite data). Panel A of Table X presents descriptive statistics for the application and infusions amounts, Application and Infusion, respectively. The average application is $\$ 374$ million and the average infusion is $\$ 372$ million. For each bank, we measure the ratio of the infusion to the application $($ Ratio = Infusion $/$ Application). For nearly all banks, this ratio is one. Panel A shows that percentiles of Application and Infusion are identical, and that the $1^{\text {st }}$ percentile of Ratio is $71 \%$ and the $99^{\text {th }}$ percentile is $102 \%$. With rare exception, banks appear to receive all the money they requested.

Panel B of Table $\mathrm{X}$ sorts infusions into three groups: infusions with Ratio $<1(\mathrm{~N}=11$ infusions), infusions with Ratio $=1(\mathrm{~N}=91$ infusions), and infusions with Ratio $>1(\mathrm{~N}=3$ infusions). Counterintuitively, Panel B suggests that firms with politically connected insiders did not receive larger infusions when measured relative to their application. (Connected decreases from 0.73 , to 0.40 , to 0.33 across the three groups). ${ }^{21}$ Panel B also suggests that insider buying prior to the infusion anticipates the gap between the infusion amount and the application amount. The probability that insiders buy 30 days before the infusion, Buyer $(-30,-1)$, monotonically increases from 0.45 , to 0.60 , to 1.00 across the three groups. We caution however, that the data is based on very small samples and that any corresponding regression results are identified by only a handful of observations (e.g., 14 infusions with insider trades and Ratio $\neq 1$ ).

\footnotetext{
${ }^{21}$ Duchin and Sosyura (2012) examine whether the likelihood of participation in TARP varies with political connections, but not - conditional on participation — whether the amount of infusion varies with connections.
} 
Panel C presents results from estimating the determinants of front-running activity, Buyer $(-30,-1)$, as a function of subsequent announcement period returns, AnncRet, and the wedge between the infusions and application amount, Ratio. Our motivation for this regression is extant noisy rational expectations models that suggest informed traders' demand orders in period $t$ are a function of private information that will be realized in period $t+1$ (e.g., Kyle, 1985). Column (1) of Panel C shows that front-running activity of politically connected insiders not only anticipates the subsequent three-day market reaction to the infusion ( $t$-stat on AnncRet of 1.84), but also anticipates the wedge between the infusion and application amount ( $t$-stat on Ratio of 2.22). Columns (2) and (3) show that this phenomenon is unique to the trades of politically connected insiders: we find no evidence that the trades among insiders without connections anticipates either the reaction to the infusion or the amount of the infusion. ${ }^{22}$ Collectively, the findings suggest politically connections provided insiders with the ability to front-run TARP infusions.

\section{Conclusion}

We examine whether political connections facilitate opportunistic behavior by corporate insiders. We focus our analysis on one particular form of opportunism — informed trading. We find no evidence of a relation between political connections and informed trading over the 24 months leading up to the Crisis, or during the Crisis before the creation of TARP (i.e., prior to October 2008). In contrast, over the nine months after the creation of TARP (i.e., the period in which TARP funds were disbursed), we find strong evidence of a relation between political

\footnotetext{
${ }^{22}$ Table IA.VII of the Internet Appendix reports results from estimating the regressions in Panel C of Table 7 after including Ratio as an additional explanatory variable. Inferences in Panel $\mathrm{C}$ of Table 7 are unaffected. After controlling for trades that front-run the infusion, we find no evidence of an incremental relation between Ratio and announcement returns.
} 
connections and informed trading by officers and directors at leading financial institutions.

During the period TARP funds were disbursed, the difference in one-month-ahead future returns between purchases and sales of insiders with (without) political connections is both economically and statistically significant, $8.89 \%(2.81 \%)$. These findings are robust to a battery of sensitivity analyses including using various fixed effect structures to control for firm-specific characteristics, changes in market conditions, and a differential effect of market conditions on firms with and without politically connected insiders.

We conduct two additional sets of analyses to strengthen empirical identification and speak to potential sources of politically connected insiders' information advantage. First, we use detailed data on officers' and directors' work history disclosed in proxy statement biographies to construct a partial network map. While undoubtedly incomplete, this map enables us to trace the nature of the political connection, the degrees of separation, and the recency of the connection. We then correlate attributes of insiders' connection with their trading behavior. Within the set of insiders with political connections, we find that the information advantage is most pronounced among insiders with recent, direct connections. Additionally, we find that individuals that sit on the same board as these directly connected insiders also experience a modest advantage over individuals on unconnected boards. These findings are consistent with political connections providing an information advantage which is partially (but incompletely) transferred to other board members at the firm.

Second, we examine insider trades thirty days prior to TARP infusions. Evidence of elevated informed trading among politically connected insiders in a short window prior to the TARP infusion would suggest these insiders are trading based on superior information about TARP infusions. Notably, we find evidence of abnormal trading by politically connected insiders 
30 days in advance of TARP infusions, and that these trades anticipate both the market reaction to the infusion and the wedge between the amount of the infusion and the application amount. We find no evidence of abnormal trading or predictive ability among unconnected insiders; insiders without political connections do not appear to time their trades to coincide with TARP infusions. These findings suggest that insiders' political connections provide them with the ability to front-run TARP infusions.

Our collective results suggests that officers' and directors' political connections can facilitate opportunism: politically connected insiders had a significant information advantage during the Crisis and traded to exploit this advantage. 


\section{References}

Aboody, David, and Baruch Lev, 2000, Information asymmetry, R\&D, and insider gains, Journal of Finance 60, 2747-2766.

Acemoglu, Daron, Simon Johnson, Amir Kermani, James Kwak, and Todd Mittone, 2016, The value of connections in turbulent times: Evidence from the United States, Journal of Financial Economics 121, 368-391.

Acharya, Viral V., and Matthew P. Richardson, 2009, Restoring financial stability: how to repair a failed system, Ed. Wiley.

Ahern, Kenneth R., 2017, Information networks: Evidence from illegal insider trading tips, Journal of Financial Economics 125, 26-47.

Akin, Ozlem, Nicholas S. Coleman, Christian Fons-Rosen, and José Luis Peydró, 2018, Political connections: Evidence from insider trading around TARP, Working Paper, Universitat Pompeu Fabra.

Appelbaum, Binyamin, and Lori Montgomery, 2008, Citing grave financial threats, officials ready massive rescue, Washington Post, September 19, 2008.

Bayazitova, Dinara, and Anil Shivdasani, 2012, Assessing TARP, Review of Financial Studies 25, 377-407.

Bebchuk, Lucien A., Alma Cohen, and Holger Spamann, 2010, The wages of failure: Executive compensation at Bear Stearns and Lehman 2000-2008, Yale Journal on Regulation 27, 257 282.

Bettis, J. Carr, Jeffrey L. Coles, and Michael L. Lemmon, 2000, Corporate policies restricting trading by insiders, Journal of Financial Economics 57, 191-220.

Bhagat, Sanjai, and Brian Bolton, 2014, Financial crisis and bank executive incentive compensation, Journal of Corporate Finance 25, 313-341.

Bourveau, Thomas, Renaud Coulomb, and Marc Sangnier, 2018, Political connections and white-collar crime: Evidence from insider trading in France, Available at SSRN: https://ssrn.com/abstract=2848096.

Brown, Jennifer L., Katharine Drake, and Laura Wellman, 2015, The benefits of a relational approach to corporate political activity: evidence from political contributions to tax policymakers, Journal of the American Taxation Association 37, 69-102.

Brunnermeier, Markus K., 2009. Deciphering the liquidity and credit crunch 2007-2008, Journal of Economic Perspectives 23, 77-100.

Cao, Ying, Dan Dhaliwal, Zengquan Li, and Yong George Yang, 2015, Are all independent directors equally informed? Evidence based on their trading returns and social networks, Management Science 61, 795-813.

Cheng, Ing-Haw, Sahil Raina, and Wei Xiong, 2013, Wall Street and the housing bubble, American Economic Review 104, 2797-2829.

Christensen, Dane M., Michael B. Mikhail, Beverly R. Walther, and Laura A. Wellman, 2017, From K street to Wall street: Political connections and stock recommendations. The Accounting Review 92, 87-112.

Claessens, Stijn, Erik Feijen, and Luc Laevenac, 2008, Political connections and preferential access to finance: the role of campaign contributions, Journal of Financial Economics 88, 554-580.

Cohen, Lauren, Andrea Frazzini, and Christopher Malloy, 2008, The small world of investing: Board connections and mutual fund managers, Journal of Political Economy 116, 951-979. 
Cohen, Lauren, Andrea Frazzini, and Christopher Malloy, 2010, Sell-side school ties, Journal of Finance, 65, 1409-1437.

Cohen, Lauren, Christopher Malloy, and Lukasz Pomorski, 2012, Decoding inside information, Journal of Finance 67, 1009-1043.

Cooper, Michael J., Huseyin Gulen, and Alexei V. Ovtchinnikov, 2010, Corporate political contributions and stock returns, Journal of Finance 65, 687-724.

Correia, Maria M., 2014, Political connections, SEC enforcement and accounting quality, Journal of Accounting and Economics 57, 241-262.

Cox, Jeff, 2017, Richmond Fed President Lacker says he was involved with Medley leak, announces immediate resignation, $\underline{C N B C}$, April 4, 2017.

Duchin, Ran, and Denis Sosyura, 2012, The politics of government investment, Journal of Financial Economics 106, 24-48.

Faccio, Mara, 2006, Politically connected firms, American Economic Review 96, 369-386.

Faccio, Mara, Ronald W. Masulis, and John J. McConnell, 2006, Political connections and corporate bailouts, Journal of Finance 61, 2597-2635.

Fahlenbrach, Rüdiger, and René M.Stulz, 2011, Bank CEO incentives and the credit crisis, Journal of Financial Economics 99, 11-26.

Farruggio, Christian, Tobias C. Michalak, and Andre Uhde, 2013, The light and dark side of TARP, Journal of Banking and Finance 37, 2586-2604.

Gao, Meng, and Jiekun Huang, 2016, Capitalizing on Capitol Hill: Informed trading by hedge fund managers, Journal of Financial Economics 121, 521-45.

Goldman, Eitan, Jörg Rocholl, and Jongil So, 2009, Do politically connected boards affect firm value? Review of Financial Studies 22, 2331-2360.

Goldman, Eitan, Jörg Rocholl, and Jongil So, 2013, Politically Connected Boards of Directors and The Allocation of Procurement Contracts, Review of Finance 17, 1617-1648.

Hamburger, Tom, 2013, Political intelligence firms set up investor meetings at White House, Washington Post, May 26, 2013.

Henning, Peter J., 2013, The fine line between political intelligence and insider trading, $\underline{\mathrm{New}}$ York Times, April 8, 2013.

Hulse, Carl,and David M. Herszenhorn, 2008, Defiant House rejects huge bailout; next step is uncertain, New York Times, Sep 30, 2008.

Jagolinzer, Alan D., David F. Larcker D, and Daniel J. Taylor, 2011, Corporate governance and the information content of insider trades, Journal of Accounting Research 49, 1249-1274.

Jeng, Leslie A, Andrew Metrick and Richard Zeckhauser, 2003, Estimating the returns to insider trading: A performance-evaluation perspective, Review of Economics and Statistics 85, 453471.

Khwaja, Asim Ijaz, and Atif Mian, 2005, Do lenders favor politically connected firms? Rent provision in an emerging financial market, Quarterly Journal of Economics 120, 1371-1411.

Kim, Seil, 2016, Information disclosure and insider trading around board meetings, Available at SSRN: https://ssrn.com/abstract=2765156.

Kyle, Albert S., 1985, Continuous auctions and insider trading, Econometrica 53, 1315-1335.

Lakonishok, J., Lee, I., 2001. Are insider trades informative? Review of Financial Studies 14, $79-111$.

Landler, Mark, and Eric Dash, 2008, Drama behind a \$250 billion banking deal, New York Times, October 14, 2008. 
Leuz, Christian, and Felix Oberholzer-Gee, 2006, Political relationships, global financing, and corporate transparency: Evidence from Indonesia, Journal of Financial Economics 81, 411439.

McCoy, Kevin, 2014, Court fight bares SEC insider-trading probe, USA Today, June 26, 2014.

Mian, Atif, Amir Suffi, and Francesco Trebbi, 2010, The political economy of the U.S. mortgage default crisis, American Economic Review 100, 1967-1998.

Mullins, Brody, and Aruna Viswanatha, 2016, The king of "political intelligence" faces a reckoning, Wall Street Journal, August 18, 2016.

$\mathrm{Ng}$, Tee Yong Jeffrey, Florin P. Vasvari, and Regina Wittenberg-Moerman, 2011, The impact of TARP's capital purchase program on the stock market valuation of participating banks, Working Paper, Singapore Management University.

Piotroski, Joseph D., and Darren T. Roulstone, 2005, Do insider trades reflect both contrarian beliefs and superior knowledge about future cash flow realizations? Journal of Accounting and Economics 39, 55-81.

Ravina, Enrichetta and Paola Sapienza, 2010, What do directors know? Evidence from their trading, Review of Financial Studies 23, 962-1003.

Ritter, Jay R., 2008, Forensic finance, Journal of Economic Perspectives 22, 127-147.

Ryan, Stephen G., Jennifer Wu Tucker, and Ying Zhou, 2016, Securitization and insider trading, The Accounting Review 91, 649-675.

Schweizer, Peter, 2011, Throw them all out: How politicians and their friends get rich off insider stock tips, land deals, and cronyism that would send the rest of us to prison, Houghton Mifflin Harcourt, Boston, MA.

Sorkin, Andrew Ross, 2009, Too big to fail: The inside story of how Wall Street and Washington fought to save the financial system, Penguin Group, New York, NY.

Tahoun, Ahmed, 2014, The role of stock ownership by US members of Congress on the market for political favors, Journal of Financial Economics 111, 86-110.

Tahoun, Ahmed, and Laurence Van Lent, 2013, Personal wealth interests of politicians and government intervention in the economy, Available at SSRN: https://ssrn.com/abstract=1570219.

Veronesi, Pietro, and Luigi Zingales, 2010, Paulson's gift, Journal of Financial Economics 97, 339-368.

Yu, Frank, and Xiaoyun Yu, 2011, Corporate lobbying and fraud detection, Journal of Financial and Quantitative Analysis 46, 1865-1891.

Viswanatha, Aruna, Kate Davidson, Brody Mullins, and Christopher M. Matthews, 2015, Questions about leak at Federal Reserve escalate to insider-trading probe, Wall Street Journal, September 30, 2015.

Ziobrowski, Alan J., Ping Cheng, James W. Boyd, and Brigitte J. Ziobrowski ,2004, Abnormal returns from the common stock investments of the U.S. Senate, Journal of Financial and Quantitative Analysis 39, 661-676. 


\section{Figure 1. Dollar value of purchases and sales by time period}

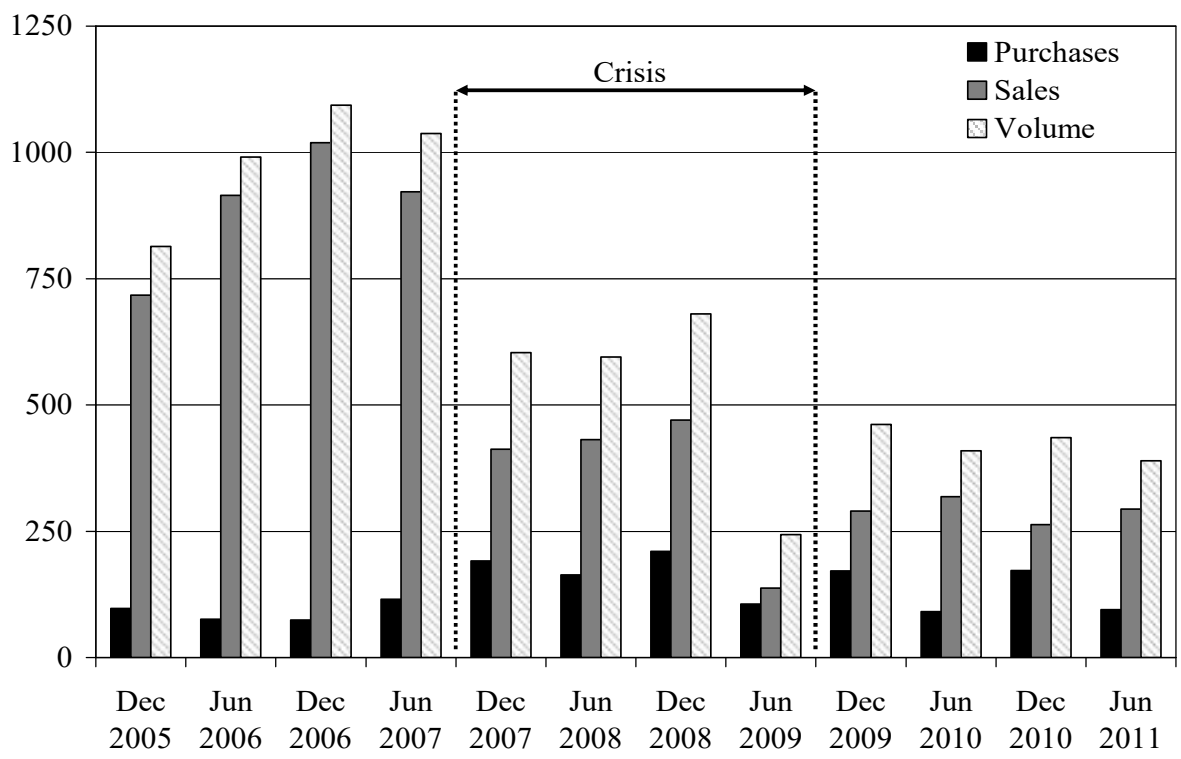

This figure plots the total dollar value of insider trades for all firms in our sample over the respective six month interval. Total dollar value of insider trades (in millions) appears on the $y$-axis, and the respective six month window appears on the $x$-axis. Black bars represent the total dollar value of purchases, gray bars represent the total dollar values of sales, and white bars represent the total dollar value of purchases plus sales, i.e., insider volume.

\section{Figure 2. Difference in Future Returns Between Purchases and Sales}

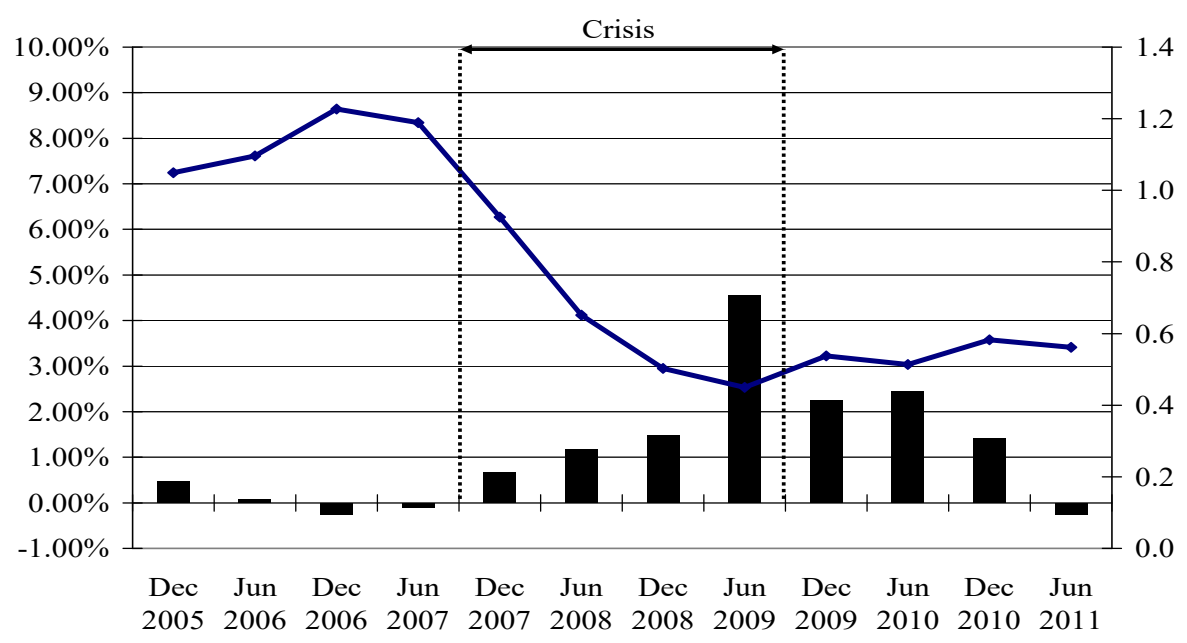

This figure plots the difference in one-month-ahead future returns between net purchase and net sales, averaged over the respective six month interval (black bars). We net all trades to the insider-month level and group observations based on whether the net trade in month $t$ was a purchase or a sale. We report the difference in one-month-ahead future returns (i.e., returns in month $t+1$ ) between net purchases and net sales. We overlay the value of a $\$ 1$ investment in the Fama-French banking portfolio invested at the end of June 2005 (solid line). 


\section{Figure 3. Political Connections and the Difference in Future Returns}

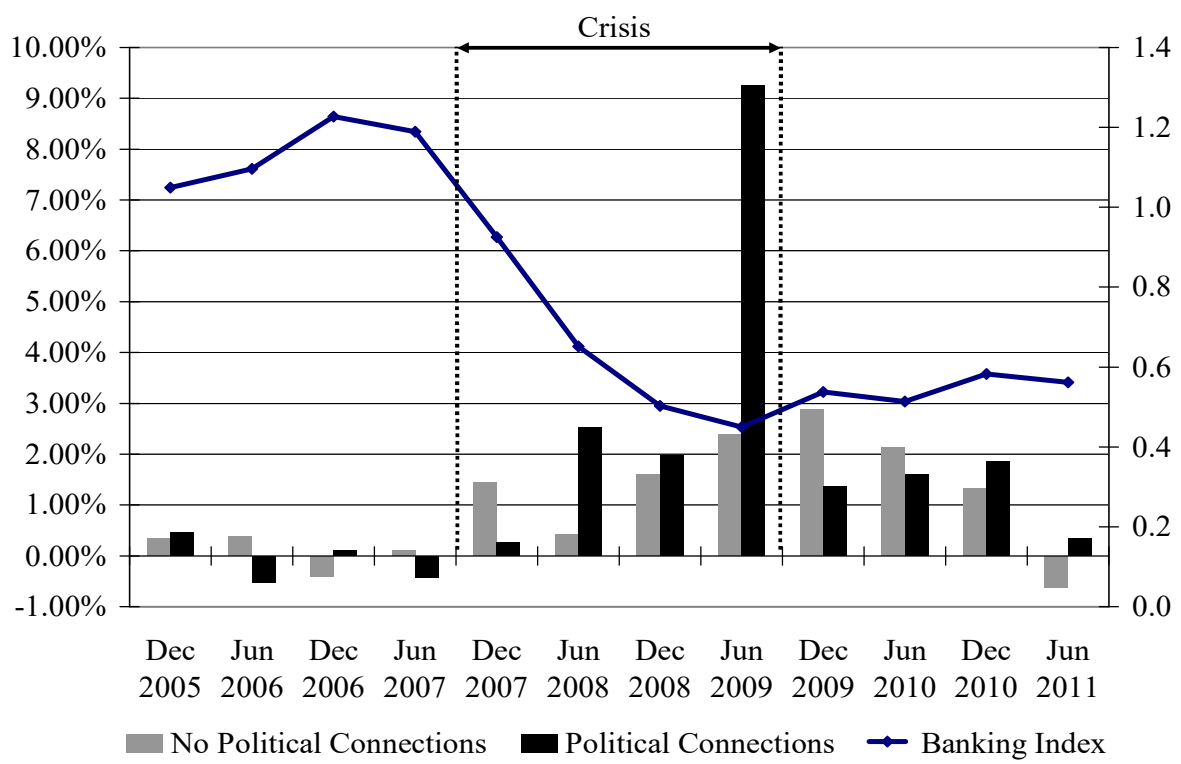

This figure plots the difference in one-month-ahead future returns between net purchase and net sales, averaged over the respective six month interval (black bars). We net all trades to the insider-month level and group observations based on whether the insider is politically connected and whether the net trade in month $t$ was a purchase or a sale (2 $\mathrm{x} 2$ ). We report the difference in one-month-ahead future returns (i.e., returns in month $t+1$ ) between net purchases and net sales separately for insiders with and without political connections. We overlay the value of a $\$ 1$ investment in the Fama-French banking portfolio invested at the end of June 2005 (solid line). 


\section{Figure 4. Example of a Partial Network Map}

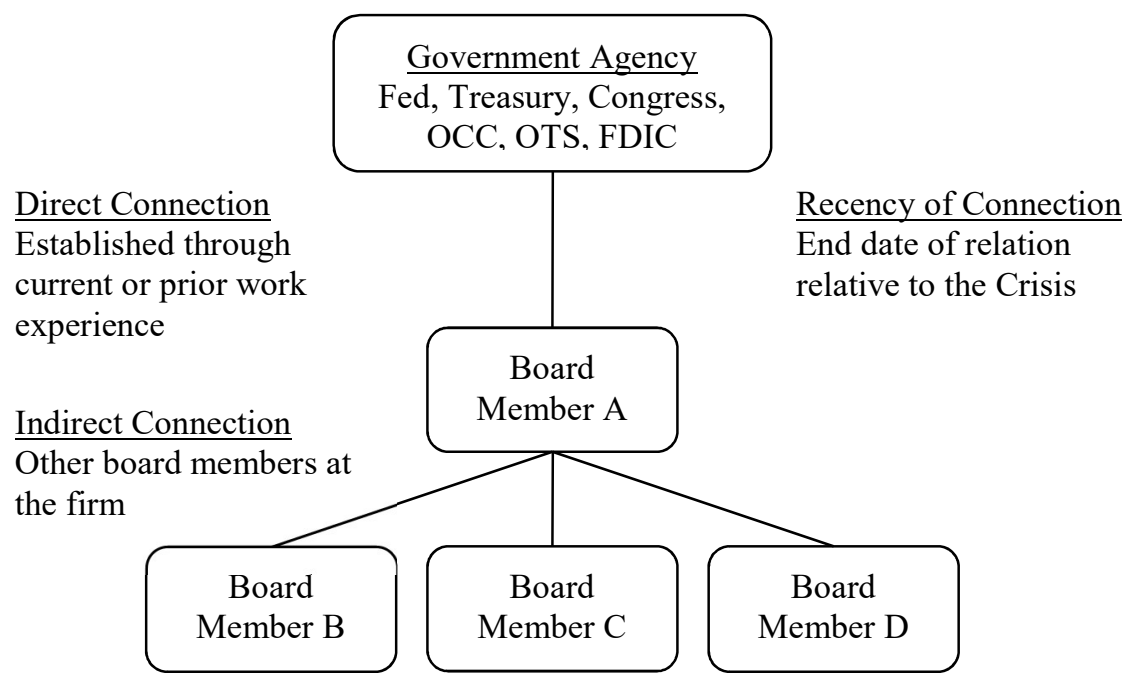

This figure presents an example of a "partial network map" used to test for information sharing among board members. We use BoardEx to determine whether a particular board member has work experience at either the Federal Reserve, Treasury Department, Congress, Office of Comptroller of Currency (OCC), Office of Thrift Supervision (OTS), or Federal Deposit Insurance Corporation (FDIC). Those board members with work experience at any of these agencies beginning prior to 2008 are classified as "directly connected." All other officers and directors at those firms are classified as "indirectly connected." Recency is the ending year of the work experience relative to 2008. For example, if a director stepped down from the Federal Reserve Board in 2005, then Recency is 3 . If the work experience continues through 2008, the connection is considered current, and Recency is coded as zero. We consider a connection "recent" if it is less than or equal to three years old (where three is the median). 
Figure 5. Unsigned Volume of Insider Trades Around Infusion Announcements

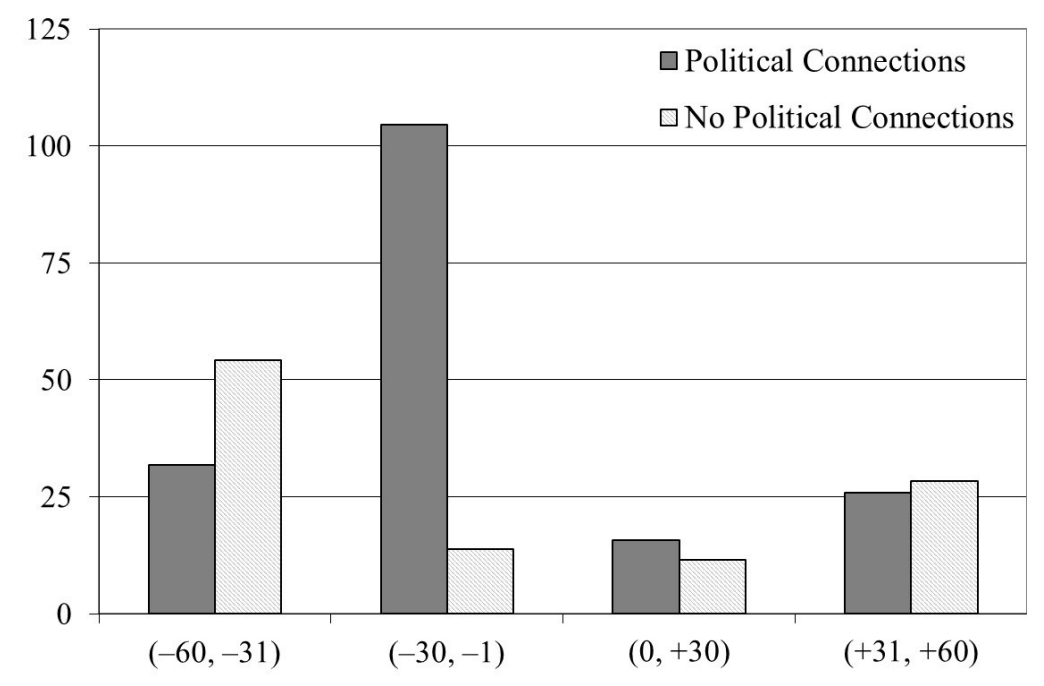

This figure shows the dollar value of insider trading volume over the 60 trading days before and after infusion announcements, i.e., $-60 \ldots,+60$. Dollar volume (in millions) appears on the $y$-axis, and the respective 30 day window appears on the $x$-axis. Gray (white) bars represent dollar volume by insiders with (without) political connections. Sample of 256 infusions. 
Figure 6. Net Purchases Around Infusion Announcements

Panel A. Net Purchases Before Infusions with Positive Announcement Returns

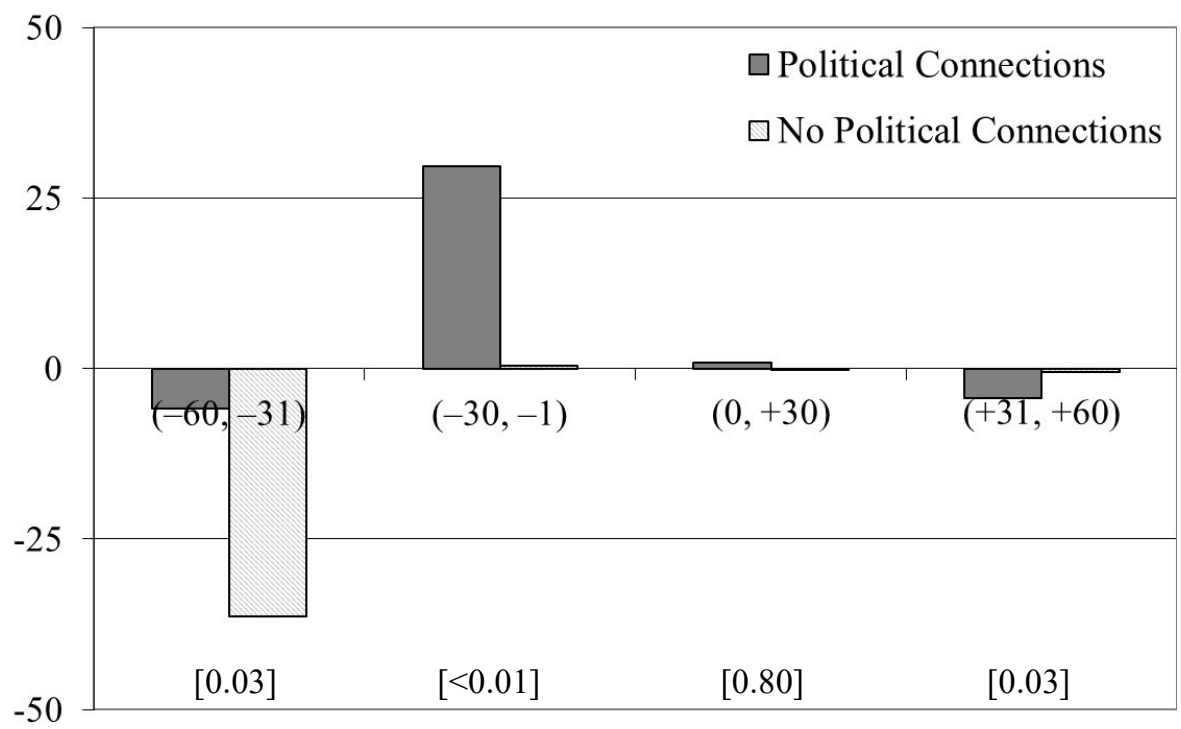

Panel B. Net Purchases Before Infusions with Negative Announcement Returns

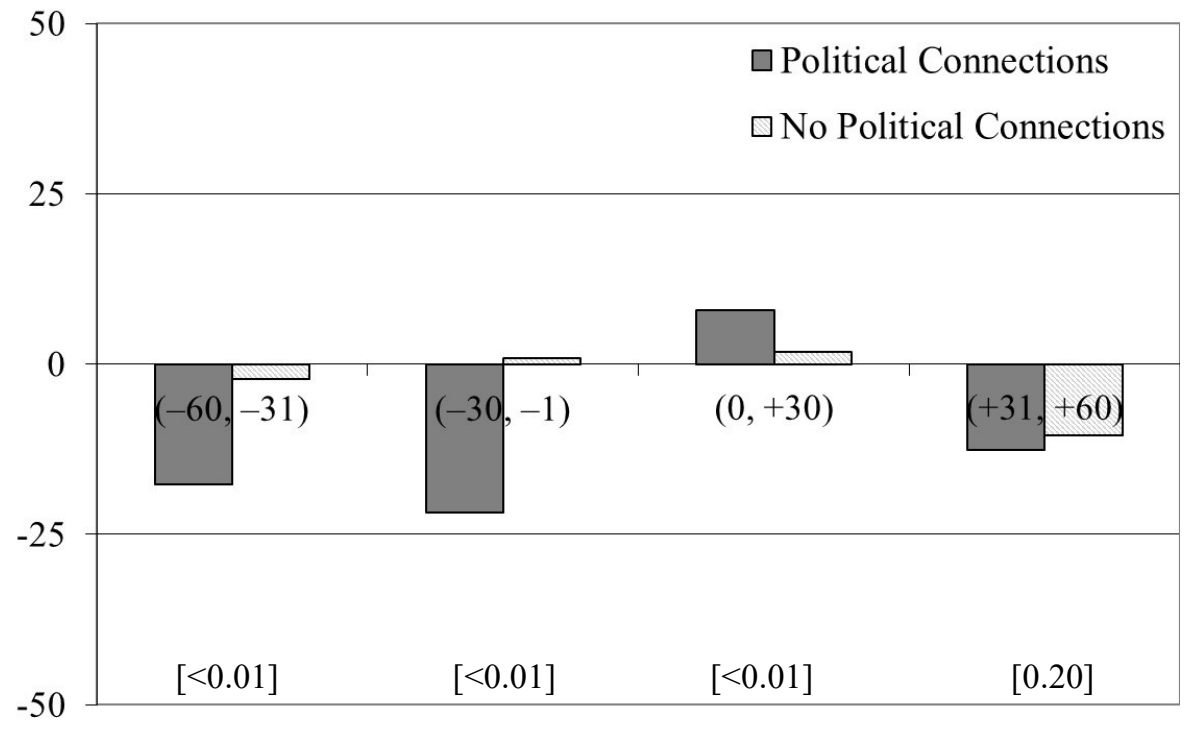

This figure shows the dollar value of net purchases (dollar value of buys less that of sales) over the 60 trading days before and after the infusion announcement, i.e., $-60 \ldots,+60$. Positive (negative) values indicate a net buy (net sell). Panel A presents the dollar value of net purchases for the 122 infusions with positive announcement returns. Panel B presents the dollar value of net purchases for the 134 infusions with negative announcement returns. Dollar value of insider trades (in millions) appears on the $y$-axis, and the respective 30 day window appears on the $x$-axis. Gray (white) bars represent the dollar values of net purchases by insiders with (without) political connections. $p$-values appear in brackets and test for the difference in average trade size between insiders with and without political connections. 


\section{Table I. Descriptive Statistics}

This table presents descriptive statistics for variables used in our tests. Panel A present descriptive statistics for firm characteristics. Panel B presents descriptive statistics for insider trades. Size is the natural log of market value at the end of month $t$. BM is the book-to-market ratio at the end of month $t$, where book value is from the prior quarter-end. PastMoRet is the return in month $t-1$. PastYrRet is the buy-and-hold return over the past year from month $t-2$ to $t-12$. NumPolConn is the number of members on the firm's board of directors with current or previous work experience at the Federal Reserve, a bank regulator (FDIC, OTS, or OCC), Treasury, or Congress, and Connected is an indicator equal to one if at least one member has such experience. TARPRecipient is an indicator variable equal to one if the firm received TARP funds. Buyer ${ }_{t}$ is an indicator variable equal to one if the number of shares bought by insider $i$ in firm $j$ in month $t$ exceeds the number of shares sold by insider $i$ in firm $j$ in month $t$. $B H R_{t+1}\left(B H R_{t+6}\right)$ is the buy-andhold return over the month (six months) subsequent to the trade. \#Unique Firms (\#Unique Insiders) is the number of unique firms (insiders) in the respective sample. Total Purchases (Total Sales) is the total dollar value of insider purchases (sales) in the respective sample.

Panel A. Firm-level characteristics

\begin{tabular}{lrrrrr}
\hline \hline Variable & Mean & Std & P25 & P50 & P75 \\
\hline Size & 5.59 & 1.85 & 4.25 & 5.33 & 6.53 \\
BM & 1.02 & 0.85 & 0.53 & 0.75 & 1.17 \\
PastMoRet & -1.78 & 11.58 & -6.28 & -0.68 & 3.78 \\
PastYrRet & -5.11 & 28.71 & -21.05 & -2.55 & 10.98 \\
NumPolConn & 0.58 & 1.13 & 0.00 & 0.00 & 1.00 \\
Connected & 0.34 & 0.47 & 0.00 & 0.00 & 1.00 \\
TARPRecipient & 0.56 & 0.50 & 0.00 & 1.00 & 1.00 \\
\hline \hline
\end{tabular}

Panel B. Trade-level characteristics

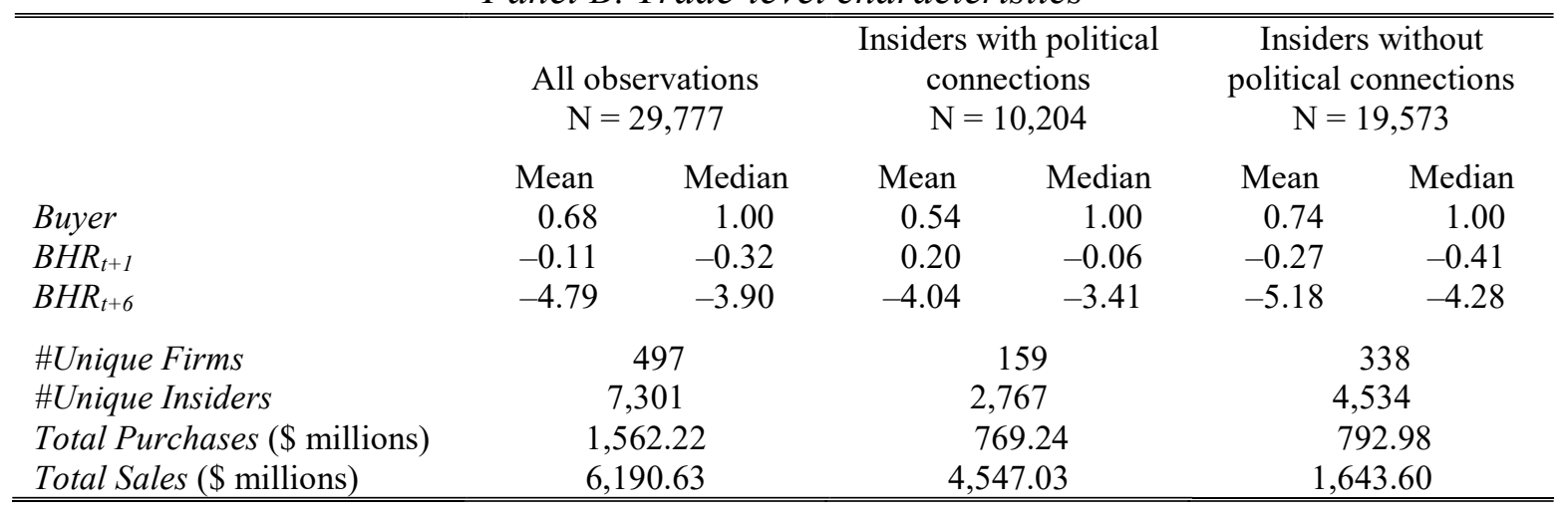




\section{Table II. Trading Activity During the Financial Crisis}

This table presents descriptive statistics for insider trading variables over time. Panel A presents number of trades, average values of Buyer, the total dollar value of purchases and sales (in millions), and the ratio of the value of purchases to sales. Panel B partitions the sample based on political connections of the insider. For each sample partition, Panel B reports the number of trades, average values of Buyer, and the fraction of total dollar value of purchases and sales (in percent). All trades are aggregated to the insider-month level. An insider is coded as having political connections if a member of the firm's board of directors has current or previous work experience at the Federal Reserve, a bank regulator (FDIC, OTS, or OCC), Treasury, or Congress.

Panel A. Insider Trading Activity by Period

\begin{tabular}{llccccc}
\hline \multicolumn{1}{l}{ Panel A. Insider Trading Activity by Period } \\
Time period & Date Range & $\begin{array}{c}\text { Num. } \\
\text { Obs. }\end{array}$ & $\begin{array}{c}\text { Avg. } \\
\text { Buyer }\end{array}$ & $\begin{array}{c}\text { Total Purchases } \\
\text { (\$ millions) }\end{array}$ & $\begin{array}{c}\text { Total Sales } \\
\text { (\$ millions) }\end{array}$ & $\begin{array}{c}\text { Purchases } \\
\text { / Sales }\end{array}$ \\
\hline Full Sample & Jul 05 - Jun 11 & 29,777 & 0.68 & 1562.22 & 6190.63 & 0.25 \\
\hline 24 mos. before the Crisis & Jul 05 - Jun 07 & 10,278 & 0.55 & 362.22 & 3573.32 & 0.10 \\
Crisis: Pre-Bailout & Jul 07 - Sep 08 & 7,625 & 0.76 & 443.15 & 1078.84 & 0.41 \\
Crisis: Bailout & Oct 08 - Jun 09 & 4,298 & 0.78 & 227.67 & 372.06 & 0.61 \\
24 mos. after the Crisis & Jul 09-Jun 11 & 7,576 & 0.70 & 529.18 & 1166.41 & 0.45 \\
\hline \hline
\end{tabular}

Panel B. Political Connections and Insider Trading Activity by Period

\begin{tabular}{|c|c|c|c|c|c|c|c|}
\hline \multirow[b]{2}{*}{ Time period } & \multirow[b]{2}{*}{ Date Range } & \multicolumn{3}{|c|}{$\begin{array}{l}\text { Insiders with Political } \\
\text { Connections }\end{array}$} & \multicolumn{3}{|c|}{$\begin{array}{l}\text { Insiders without Political } \\
\text { Connections }\end{array}$} \\
\hline & & $\begin{array}{l}\text { Avg. } \\
\text { Buyer }\end{array}$ & $\begin{array}{c}\% \text { Total } \\
\text { Purchases } \\
\text { in Panel A }\end{array}$ & $\begin{array}{l}\text { \%Total } \\
\text { Sales in } \\
\text { Panel A }\end{array}$ & $\begin{array}{l}\text { Avg. } \\
\text { Buyer }\end{array}$ & $\begin{array}{c}\% \text { Total } \\
\text { Purchases } \\
\text { in Panel A }\end{array}$ & $\begin{array}{l}\text { \%Total } \\
\text { Sales in } \\
\text { Panel A }\end{array}$ \\
\hline Full Sample & Jul 05 - Jun 11 & 0.54 & 49.24 & 73.45 & 0.74 & 50.76 & 26.55 \\
\hline 24 mos. before the Crisis & Jul 05 - Jun 07 & 0.39 & 42.22 & 73.23 & 0.64 & 57.78 & 26.77 \\
\hline Crisis: Pre-Bailout & Jul $07-$ Sep 08 & 0.64 & 42.92 & 80.90 & 0.83 & 57.08 & 19.10 \\
\hline Crisis: Bailout & Oct $08-$ Jun 09 & 0.74 & 71.08 & 43.78 & 0.80 & 28.92 & 56.22 \\
\hline 24 mos. after the Crisis & Jul 09 - Jun 11 & 0.57 & 49.94 & 76.74 & 0.77 & 50.06 & 23.26 \\
\hline
\end{tabular}




\section{Table III. Average Future Returns}

This table presents average future returns following insider trades. Panel A reports average one-month-ahead future returns separately for net purchases $($ Buyer $=$ 1 ) and net sales $($ Buyer $=0)$. Panel B presents average one-month-ahead future returns separately for each of four groups $(2 \times 2)$ : whether the insider is politically connected and whether the trade was a net purchase or a net sale. All trades are aggregated to the insider-month level. An insider is coded as having political connections if a member of the firm's board of directors has current or previous work experience at the Federal Reserve, a bank regulator (FDIC, OTS, or OCC), Treasury, or Congress. $t$-statistics appear in parentheses and test for a difference in means. ${ }^{* * *},{ }^{* *}$, and ${ }^{*}$ denote statistical significance at the $0.01,0.05$, and 0.10 levels (two-tail), respectively.

Panel A. Average Future Returns by Period

\begin{tabular}{llccrr}
\hline \hline Time period & Date Range & $\begin{array}{c}B H R_{t+1} \\
\text { following } \\
\text { Purchases }\end{array}$ & $\begin{array}{c}B H R_{t+1} \\
\text { following } \\
\text { Sales }\end{array}$ & $\begin{array}{c}\text { Difference in } \\
B H R_{t+1}\end{array}$ \\
\hline Full Sample & Jul 05 - Jun 11 & 0.23 & -0.82 & $\mathbf{1 . 0 5}^{* * *}$ & $(6.76)$ \\
\hline 24 mos. before the Crisis & Jul 05 - Jun 07 & -0.24 & -0.10 & -0.14 & $(-1.44)$ \\
Crisis: Pre-Bailout & Jul 07 - Sep 08 & -1.35 & -2.49 & $\mathbf{1 . 1 4}^{* * *}$ & $(3.12)$ \\
Crisis: Bailout & Oct 08 - Jun 09 & 1.84 & -2.87 & $\mathbf{4 . 7 1}^{* * *}$ & $(6.18)$ \\
24 mos. after the Crisis & Jul 09-Jun 11 & 1.44 & -0.14 & $\mathbf{1 . 5 8}^{* * *}$ & $(4.99)$ \\
\hline \hline
\end{tabular}

Panel B. Political Connections and Average Future Returns by Period

\begin{tabular}{|c|c|c|c|c|c|c|c|c|c|c|c|}
\hline \multirow{2}{*}{$\begin{array}{l}\text { Label } \\
\text { Full Sample }\end{array}$} & \multirow{2}{*}{$\begin{array}{l}\text { Date Range } \\
\text { Jul } 05 \text { - Jun } 11 \\
\end{array}$} & \multirow{2}{*}{$\begin{array}{c}\begin{array}{c}\text { Inside } \\
B H R_{t+1} \\
\text { following } \\
\text { Purchases }\end{array} \\
1.03 \\
\end{array}$} & \multirow{2}{*}{$\begin{array}{c}\text { with Politic } \\
\begin{array}{c}B H R_{t+1} \\
\text { following } \\
\text { Sales }\end{array} \\
-0.79 \\
\end{array}$} & \multicolumn{2}{|c|}{$\begin{array}{c}\text { Difference in } \\
B H R_{t+1}\end{array}$} & $\begin{array}{c}\text { Insiders } \\
B H R_{t+1} \\
\text { following } \\
\text { Purchases } \\
\end{array}$ & $\begin{array}{l}\text { without Poli } \\
\qquad B H R_{t+1} \\
\text { following } \\
\text { Sales } \\
\end{array}$ & $\begin{array}{r}\text { Differ } \\
B H \\
\end{array}$ & $\begin{array}{l}\text { nce in } \\
t_{t+1}\end{array}$ & \multicolumn{2}{|c|}{$\begin{array}{c}\text { Difference } \\
\text {-in- } \\
\text { Differences }\end{array}$} \\
\hline & & & & $1.81^{* * *}$ & $(6.92)$ & -0.07 & -0.86 & $0.79^{* * *}$ & $(3.90)$ & $1.02^{* * *}$ & $(3.16)$ \\
\hline 24 mos. before the Crisis & Jul 05 - Jun 07 & -0.44 & -0.07 & -0.37 & $(-2.34)$ & -0.17 & -0.12 & -0.05 & $(-0.37)$ & -0.32 & $(-1.50)$ \\
\hline Crisis: Pre-Bailout & Jul $07-\operatorname{Sep} 08$ & -0.27 & -2.07 & $1.80^{* * *}$ & $(2.82)$ & -1.79 & -2.93 & $1.14^{* * *}$ & $(2.49)$ & 0.66 & $(0.89)$ \\
\hline Crisis: Bailout & Oct 08 - Jun 09 & 5.00 & -3.89 & $8.89^{* * *}$ & $(5.96)$ & 0.53 & -2.28 & $2.81^{* * *}$ & $(3.23)$ & $6.08^{* * *}$ & $(3.81)$ \\
\hline 24 mos. after the Crisis & Jul 09 - Jun 11 & 1.31 & -0.19 & $1.50^{* * *}$ & $(3.72)$ & 1.48 & -0.09 & $1.57^{* * *}$ & $(3.46)$ & -0.07 & $(-0.10)$ \\
\hline
\end{tabular}




\section{Table IV. Political Connections and the Informativeness of Insider Trades: Between Group Analysis}

This table presents results from estimating equations (1) and (2). Panel A presents results measuring future returns over the subsequent month $(s=1)$ and Panel B presents results measuring future returns over the subsequent six months $(s=6)$. Columns (1) and (2) estimate the regression specification pooling over all observations, Columns (3) and (4) estimate the regression separately for insiders with and without political connections. Column (5) presents the difference in coefficients between (3) and (4). The coefficient on Buyer represents the informativeness of the net insider trade for future performance and the coefficient on Buyer*Crisis_Bailout represents the change in the informativeness of the trade during the "Bailout period." Crisis_PreBailout is an indicator variable equal to one for the period from July 2007 to September 2008. Crisis_Bailout is an indicator variable equal to one for the period from October 2008 to June 2009. All other variables are defined in Table I. $t$-statistics (two-tailed $p$-values) based on standard errors clustered by firm appear in parentheses (brackets). ${ }^{* * *},{ }^{* *}$, and ${ }^{*}$ denote statistical significance at the $0.01,0.05$, and 0.10 levels (two-tail), respectively. Bold denotes statistical significance at the 0.10 level or less (twotail).

Panel A. One-month ahead future returns

Dependent variable: $B H R_{i, t+1}$

\begin{tabular}{|c|c|c|c|c|c|}
\hline \multirow[b]{3}{*}{ Variables } & \multirow[b]{2}{*}{ All Obs } & \multirow[b]{2}{*}{ All Obs } & \multicolumn{3}{|c|}{ Political Connections } \\
\hline & & & Yes & No & Diff. \\
\hline & $(1)$ & $(2)$ & (3) & $(4)$ & $(5)$ \\
\hline Buyer & $\begin{array}{l}\mathbf{0 . 5 1} \\
(2.04)\end{array}$ & $\begin{array}{c}\text { 0.39* } \\
(1.66)\end{array}$ & $\begin{array}{c}-0.20 \\
(-0.45)\end{array}$ & $\begin{array}{c}\mathbf{0 . 5 5} \\
(1.94)\end{array}$ & {$[0.15]$} \\
\hline Buyer*Crisis_PreBailout & . & $\begin{array}{c}-0.05 \\
(-0.07)\end{array}$ & $\begin{array}{c}0.40 \\
(0.34)\end{array}$ & $\begin{array}{c}0.14 \\
(0.19)\end{array}$ & {$[0.85]$} \\
\hline Buyer*Crisis_Bailout & . & $\begin{array}{l}2.34^{* *} \\
(2.49)\end{array}$ & $\begin{array}{l}\mathbf{6 . 4 3}^{* * * *} \\
(3.35)\end{array}$ & $\begin{array}{c}0.63 \\
(0.62)\end{array}$ & {$[<0.01]$} \\
\hline \multicolumn{6}{|l|}{ Controls } \\
\hline Size & $\begin{array}{l}\mathbf{0 . 3 2} \\
(2.83)\end{array}$ & $\begin{array}{c}\mathbf{0 . 3 2} \\
(2.80)\end{array}$ & $\begin{array}{c}0.18 \\
(1.16)\end{array}$ & $\begin{array}{l}\mathbf{0 . 4 8} \mathbf{8}^{* *} \\
(2.53)\end{array}$ & {$[0.23]$} \\
\hline$B M$ & $\begin{array}{c}2.57^{* * *} \\
(4.61)\end{array}$ & $\begin{array}{l}\mathbf{2 . 3 3}^{* * * *} \\
(4.05)\end{array}$ & $\begin{array}{l}2.77^{* *} \\
(2.48)\end{array}$ & $\begin{array}{l}\mathbf{2 . 1 3}^{* * * *} \\
(3.40)\end{array}$ & {$[0.62]$} \\
\hline PastMoRet & $\begin{array}{l}-0.11^{* * *} \\
(-3.87)\end{array}$ & $\begin{array}{c}-0.12^{* * *} \\
(-4.11)\end{array}$ & $\begin{array}{l}-0.12^{* * *} \\
(-3.34)\end{array}$ & $\begin{array}{l}-0.12^{* * *} \\
(-2.97)\end{array}$ & {$[0.98]$} \\
\hline PastYrRet & $\begin{array}{l}\mathbf{0 . 0 4} 4^{* * *} \\
(3.67)\end{array}$ & $\begin{array}{c}\mathbf{0 . 0 2}^{*} \\
(1.79)\end{array}$ & $\begin{array}{c}0.02 \\
(1.35)\end{array}$ & $\begin{array}{c}0.02 \\
(1.41)\end{array}$ & {$[0.91]$} \\
\hline Crisis_PreBailout & & $\begin{array}{c}-2.10^{* * *} \\
(-4.28)\end{array}$ & $\begin{array}{l}-\mathbf{1 . 5 5} 5^{* *} \\
(-2.21)\end{array}$ & $\begin{array}{c}-2.66^{* * *} \\
(-4.20)\end{array}$ & {$[0.24]$} \\
\hline Crisis_Bailout & & $\begin{array}{l}-3.34^{* * *} \\
(-4.48)\end{array}$ & $\begin{array}{c}-\mathbf{5 . 0 0} \\
(-3.93)\end{array}$ & $\begin{array}{l}-2.54^{* * *} \\
(-2.95)\end{array}$ & {$[0.11]$} \\
\hline $\mathrm{F}$ & 13.24 & 12.33 & 4.71 & 10.57 & \\
\hline N(insider-months) & 29,777 & 29,777 & 10,204 & 19,573 & \\
\hline $\mathrm{N}$ (firms) & 497 & 497 & 159 & 338 & \\
\hline
\end{tabular}


Table IV. Political Connections and the Informativeness of Insider Trades: Between Group Analysis (cont'd)

Panel B. Six-month ahead future returns

\begin{tabular}{|c|c|c|c|c|c|}
\hline \multirow[b]{4}{*}{ Variables } & \multicolumn{5}{|c|}{ Dependent variable: $B H R_{i, t+6}$} \\
\hline & \multirow[b]{2}{*}{ All Obs } & \multirow[b]{2}{*}{ All Obs } & \multicolumn{3}{|c|}{ Political Connections } \\
\hline & & & Yes & No & Diff. \\
\hline & $(1)$ & $(2)$ & $(3)$ & (4) & $(5)$ \\
\hline Buyer & $\begin{array}{c}1.32 \\
(1.46)\end{array}$ & $\begin{array}{l}\mathbf{2 . 9 2}^{* * * *} \\
(3.53)\end{array}$ & $\begin{array}{l}\mathbf{4 . 3 0}^{* * * *} \\
(3.27)\end{array}$ & $\begin{array}{l}\mathbf{1 . 7 0}^{*} \\
(1.86)\end{array}$ & {$[0.10]$} \\
\hline Buyer*Crisis_PreBailout & & $\begin{array}{l}-\mathbf{3 . 5 3}^{* *} \\
(-1.99)\end{array}$ & $\begin{array}{l}-\mathbf{5 . 9 4}^{\text {*** }} \\
(-1.98)\end{array}$ & $\begin{array}{l}-\mathbf{3 . 5 9}^{*} \\
(-1.70)\end{array}$ & {$[0.52]$} \\
\hline Buyer*Crisis_Bailout & & $\begin{array}{l}\mathbf{4 . 8 3}^{*} \\
(1.87)\end{array}$ & $\begin{array}{c}\mathbf{1 8 . 7 8}^{* * * *} \\
(3.60)\end{array}$ & $\begin{array}{l}-1.39 \\
(-0.46)\end{array}$ & {$[<0.01]$} \\
\hline \multicolumn{6}{|l|}{ Controls } \\
\hline Size & 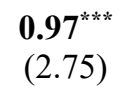 & $\begin{array}{l}\mathbf{1 . 0 7}^{* * * *} \\
(3.25)\end{array}$ & $\begin{array}{l}\mathbf{1 . 6 5}^{\text {**** }} \\
(3.57)\end{array}$ & $\begin{array}{c}0.44 \\
(0.90)\end{array}$ & {$[0.07]$} \\
\hline$B M$ & $\begin{array}{l}\mathbf{6 . 9 1} \\
(4.86)\end{array}$ & $\begin{array}{l}\mathbf{3 . 9 2}^{* * *} \\
(2.89)\end{array}$ & $\begin{array}{l}\mathbf{5 . 5 0}^{* * *} \\
(2.04)\end{array}$ & $\begin{array}{l}\mathbf{2 . 7 2}^{* * *} \\
(2.03)\end{array}$ & {$[0.36]$} \\
\hline PastMoRet & $\begin{array}{l}-\mathbf{- 0 . 0 8}^{*} \\
(-1.66)\end{array}$ & $\begin{array}{c}-\mathbf{0 . 1 7} 7^{* * * *} \\
(-3.38)\end{array}$ & $\begin{array}{l}-\mathbf{0 . 2 4} \\
(-2.56)\end{array}$ & $\begin{array}{l}-\mathbf{0 . 1 3}{ }^{* *} \\
(-2.38)\end{array}$ & {$[0.31]$} \\
\hline PastYrRet & 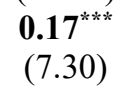 & $\begin{array}{c}\mathbf{0 . 0 8}^{* * * *} \\
(3.18)\end{array}$ & $\begin{array}{c}0.03 \\
(0.84)\end{array}$ & $\begin{array}{c}\mathbf{0 . 1 0}^{* * * *} \\
(3.44)\end{array}$ & {$[0.17]$} \\
\hline Crisis_PreBailout & $\cdot$ & $\begin{array}{c}-\mathbf{1 4 . 3 5} \\
(-11.47)\end{array}$ & $\begin{array}{c}-\mathbf{1 5 . 8 5}^{* * *} \\
(-8.29)\end{array}$ & $\begin{array}{c}-12.66 * * * \\
(-7.64)\end{array}$ & {$[0.21]$} \\
\hline Crisis_Bailout & . & $\begin{array}{c}-2.25 \\
(-1.17) \\
\end{array}$ & $\begin{array}{c}-9.47^{* * * *} \\
(-2.88) \\
\end{array}$ & $\begin{array}{c}1.51 \\
(0.67) \\
\end{array}$ & {$[<0.01]$} \\
\hline $\mathrm{F}$ & 17.38 & 41.19 & 24.66 & 20.89 & \\
\hline N(insider-months) & 29,777 & 29,777 & 10,204 & 19,573 & \\
\hline $\mathrm{N}($ firms $)$ & 497 & 497 & 159 & 338 & \\
\hline
\end{tabular}




\section{Table V. Political Connections and the Informativeness of Insider Trades: Within-Firm Analysis}

This table reports results from estimating equation (2) after including firm and date fixed effects. The dependent variable is six-month ahead future returns $\left(B H R_{i, t+6}\right)$ and all fixed effects are allowed to vary with political connections. For example, there are two vectors of date fixed effects, one for the sample of insiders with political connections and one for the sample of insiders without political connections. Because Crisis_PreBailout and Crisis_Bailout are time period indicator variables, date fixed effects subsume the main effects on Crisis PreBailout and Crisis Bailout. All variables are defined in Table I. For parsimony, coefficients on control variables are not tabulated. $t$-statistics (two-tailed $p$-values) based on standard errors clustered by firm appear in parentheses (brackets). ${ }^{* * *},{ }^{* *}$, and ${ }^{*}$ denote statistical significance at the $0.01,0.05$, and 0.10 levels (two-tail), respectively.

\begin{tabular}{|c|c|c|c|c|c|c|c|c|c|}
\hline \multirow[b]{3}{*}{ Variables } & \multicolumn{3}{|c|}{ Firm Fixed Effects } & \multicolumn{3}{|c|}{ Date Fixed Effects } & \multicolumn{3}{|c|}{ Firm + Date Fixed Effects } \\
\hline & \multicolumn{3}{|c|}{ Political Connections } & \multicolumn{3}{|c|}{ Political Connections } & \multicolumn{3}{|c|}{ Political Connections } \\
\hline & $\begin{array}{l}\text { Yes } \\
(1) \\
\end{array}$ & $\begin{array}{l}\text { No } \\
(2)\end{array}$ & $\begin{array}{c}\text { Diff } \\
(3) \\
\end{array}$ & $\begin{array}{l}\text { Yes } \\
(4)\end{array}$ & $\begin{array}{l}\text { No } \\
(5)\end{array}$ & $\begin{array}{c}\text { Diff } \\
(6)\end{array}$ & $\begin{array}{l}\text { Yes } \\
(7) \\
\end{array}$ & $\begin{array}{l}\text { No } \\
(8) \\
\end{array}$ & $\begin{array}{c}\text { Diff } \\
(9)\end{array}$ \\
\hline Buyer & $\begin{array}{l}\mathbf{2 . 7 4 ^ { * }} \\
(1.70)\end{array}$ & $\begin{array}{c}0.71 \\
(0.76)\end{array}$ & {$[0.28]$} & $\begin{array}{l}\mathbf{3 . 3 0}^{* * *} \\
(2.73)\end{array}$ & $\begin{array}{l}\mathbf{1 . 6 5}^{\text {** }} \\
(2.11)\end{array}$ & {$[0.25]$} & $\begin{array}{l}2.94^{\text {** }} \\
(2.02)\end{array}$ & $\begin{array}{c}\mathbf{1 . 4 8}^{*} \\
(1.67)\end{array}$ & {$[0.39]$} \\
\hline Buyer*Crisis_PreBailout & $\begin{array}{c}-0.29 \\
(-0.11)\end{array}$ & $\begin{array}{c}1.77 \\
(0.83)\end{array}$ & {$[0.55]$} & $\begin{array}{c}-7.15^{* * *} \\
(-2.67)\end{array}$ & $\begin{array}{l}-4.95^{* *} \\
(-2.53)\end{array}$ & {$[0.51]$} & $\begin{array}{c}-3.12 \\
(-1.32)\end{array}$ & $\begin{array}{c}-0.46 \\
(-0.23)\end{array}$ & {$[0.39]$} \\
\hline Buyer*Crisis_Bailout & $\begin{array}{c}18.29^{* * *} \\
(3.99)\end{array}$ & $\begin{array}{c}0.69 \\
(0.25)\end{array}$ & {$[<0.01]$} & $\begin{array}{c}12.13^{* * * *} \\
(2.95)\end{array}$ & $\begin{array}{c}-3.07 \\
(-1.04)\end{array}$ & {$[<0.01]$} & $\begin{array}{l}9.97^{* * *} \\
(2.71)\end{array}$ & $\begin{array}{c}-3.02 \\
(-1.08)\end{array}$ & {$[<0.01]$} \\
\hline Control Variables & Yes & Yes & & Yes & Yes & & Yes & Yes & \\
\hline Firm Fixed Effects & Yes & Yes & & No & No & & Yes & Yes & \\
\hline Date Fixed Effects & No & No & & Yes & Yes & & Yes & Yes & \\
\hline $\mathrm{F}$ & 25.88 & 22.99 & & 4.14 & 4.72 & & 3.85 & 9.89 & \\
\hline $\mathrm{N}$ (insider-months) & 10,204 & 19,573 & & 10,204 & 19,573 & & 10,204 & 19,573 & \\
\hline $\mathrm{N}$ (firms) & 159 & 338 & & 159 & 338 & & 159 & 338 & \\
\hline
\end{tabular}




\section{Table VI. Network Analysis: Attributes of the Connected Individual}

The table presents results from constructing a partial network map and analyzing the attributes of individual insiders and their connections. See Figure 4 for details. Panel A presents sample requirements for this analysis. Those board members with work experience at the Federal Reserve, Treasury Department, Congress, Office of Comptroller of Currency (OCC), Office of Thrift Supervision (OTS), or Federal Deposit Insurance Corporation (FDIC) beginning prior to 2008 are classified as "directly connected" (Connected =1, Direct Connection = 1). All other officers and directors at the same firms are classified as "indirectly connected" (Connected $=1$, Direct Connection $=0$ ). Among those with direct connections, we measure the age or "recency" of the connection relative to 2008. For example, if a director stepped down from the Federal Reserve Board in 2005, then Recency is 3. If the work experience continues through 2008, the connection is current, and Recency is coded as zero. We consider a direct connection "recent" (Direct Recent Connection $=1$ ) if Recency $\leq 3$ and "stale" (Direct Stale Connection =1) if Recency $>3$. Sample of 740 politically connected insiders who trade during the Bailout period: 72 of which have direct connections. Panel B shows the number of insiders with direct connections that are officers, and the number of insiders with direct connections that are financial experts. Officer is an indicator equal to one if the individual is an officer of the firm, and Financial Expert is an indicator equal to one if the individual satisfies the financial expert requirement of SOX. Panel $\mathrm{C}$ shows results from estimating equation (3) on the sample of trades placed during the Bailout period by insiders with political connections (Connected $=1$ and BailoutPd $=1$ ) - and distinguishing trades of indirect and direct connections, trade of recent and stale connections, trades of officer and directors, and trades of financial experts. $t$ statistics (two-tailed $p$-values) based on standard errors clustered by firm appear in parentheses (brackets). ${ }^{* * *},{ }^{* *}$, and ${ }^{*}$ denote statistical significance at the $0.01,0.05$, and 0.10 levels (two-tail), respectively.

\section{Panel A. Sample of Politically Connected Insiders Trading During the Bailout}

Number of Firms with $\geq 1$ Politically Connected Insider Trading During the Bailout Period

146 firms

After requiring BoardEx data

114 firms

Number of Connected Insiders Trading During the Bailout Period

740 insiders

Number of Officers (within connected sample)

319 of 740

Number of Financial Experts (within connected sample)

138 of 740

Number of Insiders with Direct Connections (1 degree of separation)

72 of 740

Number of Insiders with Recent Direct Connections (Recency $\leq 3$ years)

20 of 72

Number of Insiders with Stale Direct Connections (Recency $>3$ years)

52 of 72

Panel B. Separating Connections from Board Position

Officer

\begin{tabular}{ll|ccc} 
& & No & Yes & Total \\
\hline Direct Connection & No & 388 & 280 & 668 \\
& Yes & 34 & 38 & 72
\end{tabular}

Financial Expert

\begin{tabular}{ll|ccc} 
& & No & Yes & Total \\
\hline \multirow{2}{*}{ Direct Connection } & No & 547 & 121 & 668 \\
& Yes & 55 & 17 & 72 \\
\hline \hline
\end{tabular}




\section{Table VI. Network Analysis: Attributes of the Connected Individual (cont'd)}

Panel C. Within-Political Connected Insider Analysis

Dependent variable: $B H R_{i, t+6}$

Sample of Trades by Politically Connected Insiders During Bailout Period

(Observations where Connected $=1$ and Crisis Bailout $=1$ )

\begin{tabular}{|c|c|c|c|c|}
\hline & Base Model & $\begin{array}{l}\text { Direct v. Indirect } \\
\text { Connections }\end{array}$ & $\begin{array}{c}\text { Recent v. Stale } \\
\text { Direct } \\
\text { Connections }\end{array}$ & $\begin{array}{c}\text { Controlling for } \\
\text { Board Position } \\
\text { Eqn (5) }\end{array}$ \\
\hline Variables & $(1)$ & $(2)$ & $(3)$ & (4) \\
\hline Buyer & $\begin{array}{l}\mathbf{8 . 4 4}^{* * *} \\
(2.56)\end{array}$ & $\begin{array}{l}7.66^{* * *} \\
(2.30)\end{array}$ & $\begin{array}{l}\mathbf{7 . 8 3}^{* *} \\
(2.36)\end{array}$ & $\begin{array}{l}\mathbf{8 . 6 4}^{* * *} \\
(2.35)\end{array}$ \\
\hline Buyer*Direct Connection & & $\begin{array}{l}\mathbf{9 . 5 6}^{*} \\
(1.71)\end{array}$ & . & $\cdot$ \\
\hline Buyer*Recent Direct Connection & & . & $\begin{array}{c}\mathbf{3 5 . 4 1}^{* * * *} \\
(3.02)\end{array}$ & $\begin{array}{c}\mathbf{3 6 . 6 5}^{\text {**** }} \\
(3.08)\end{array}$ \\
\hline Buyer*Stale Direct Connection & & . & $\begin{array}{l}4.67 \\
(0.87)\end{array}$ & $\begin{array}{c}4.56 \\
(0.83)\end{array}$ \\
\hline Buyer*Officer & & . & . & $\begin{array}{l}-1.37 \\
(-0.28)\end{array}$ \\
\hline Buyer*Financial Expert & & . & . & $\begin{array}{c}0.79 \\
(0.12)\end{array}$ \\
\hline \multicolumn{5}{|l|}{ Controls } \\
\hline Size & $\begin{array}{l}-\mathbf{4 6 . 1 5} \\
(-2.69)\end{array}$ & $\begin{array}{l}-\mathbf{4 5 . 8 5} \\
(-2.67)\end{array}$ & $\begin{array}{c}-\mathbf{4 6 . 0 3}^{* * *} \\
(-2.68)\end{array}$ & $\begin{array}{l}-\mathbf{4 6 . 4 4}{ }^{* * * *} \\
(-2.71)\end{array}$ \\
\hline$B M$ & $\begin{array}{l}\mathbf{2 5 . 8 6}^{*} \\
(1.95)\end{array}$ & $\begin{array}{l}\mathbf{2 6 . 0 2}^{*} \\
(1.96)\end{array}$ & $\begin{array}{c}\mathbf{2 6 . 0 6}^{* *} \\
(1.97)\end{array}$ & $\begin{array}{l}\mathbf{2 5 . 9 9}^{*} \\
(1.94)\end{array}$ \\
\hline PastMoRet & $\begin{array}{l}-0.01 \\
(-0.08)\end{array}$ & $\begin{array}{l}-0.01 \\
(-0.10)\end{array}$ & $\begin{array}{l}-0.01 \\
(-0.08)\end{array}$ & $\begin{array}{l}-0.01 \\
(-0.07)\end{array}$ \\
\hline PastYrRet & $\begin{array}{l}-\mathbf{0 . 4 3} 3^{* * *} \\
(-3.35)\end{array}$ & $\begin{array}{l}-\mathbf{0 . 4 3} \\
(-3.36)\end{array}$ & $\begin{array}{l}-\mathbf{0 . 4 4} \\
(-3.45)\end{array}$ & $\begin{array}{l}-\mathbf{0 . 4 4} \\
(-3.48)\end{array}$ \\
\hline Direct Connection & & $\begin{array}{l}-5.01 \\
(-1.08)\end{array}$ & 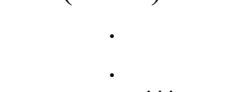 & 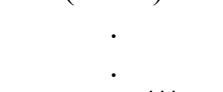 \\
\hline Recent Direct Connection & & . & $\begin{array}{l}-\mathbf{2 8 . 2 4} \\
(-2.63)\end{array}$ & $\begin{array}{l}-\mathbf{2 8 . 4 0 * * *} \\
(-2.64)\end{array}$ \\
\hline Stale Direct Connection & & . & $\begin{array}{l}-0.71 \\
(-0.17)\end{array}$ & $\begin{array}{l}-0.45 \\
(-0.10)\end{array}$ \\
\hline Officer & & . & $\cdot$ & $\begin{array}{l}-0.26 \\
(-0.07)\end{array}$ \\
\hline Financial Expert & & . & . & $\begin{array}{l}-3.80 \\
(-0.66) \\
\end{array}$ \\
\hline Firm Fixed Effects & Yes & Yes & Yes & Yes \\
\hline Date Fixed Effects & Yes & Yes & Yes & Yes \\
\hline $\mathrm{F}$ & 26.92 & 21.10 & 20.35 & 15.28 \\
\hline N(insider-months) & 1055 & 1055 & 1055 & 1055 \\
\hline $\mathrm{N}$ (firms) & 109 & 109 & 109 & 109 \\
\hline $\begin{array}{l}\text { test: } \\
\text { Buyer*Recent Direct Connection }\end{array}$ & er*Stale $D_{t}$ & Connection $=0$ & {$[<0.01]$} & {$[<0.01]$} \\
\hline
\end{tabular}




\section{Table VII. Front-Running TARP Infusions}

This table presents results for an event study of the market reaction to TARP infusions. Panel A presents descriptive statistics for key variables related to the infusion after partitioning by the direction of insider trade 30 trading days prior to the infusion announcement. Panel B presents descriptive statistics after partitioning based on the direction of insider trade and political connections $(2 \times 2)$. Panel $\mathrm{C}$ presents results from a cross-sectional regression of the threeday announcement period return on the direction of insider trading over the 30 trading days prior to the infusion and control variables. Total \# Insiders Trading is the total number of unique insiders trading over the 30 day window prior to the infusion. Total Insider Volume is the total dollar value of insider trades over the 30 day window prior to the infusion. AnncRet is the three-day buy-and-hold return centered on the infusion and expressed in percent. Infusion\%MV (Infusion\%Assets) is the amount of the infusion as a percentage of prior quarter market value (book value of total assets). Buyer $(-30,-1)$ is an indicator equal to one if the net insider trade 30 days prior to the infusion is a purchase. All other variables are as previously defined. The sample consists of 256 capital infusions across 249 firms and 31 dates, excluding the nine initial recipients. $t$-statistics (two-tailed $p$-values) based on standard errors clustered by firm appear in parentheses (brackets). ${ }^{* * *},{ }^{* *}$, and ${ }^{*}$ denote statistical significance at the $0.01,0.05$, and 0.10 levels (two-tail), respectively.

Panel A. Infusion Characteristics Partitioned by Insider Trade

\begin{tabular}{|c|c|c|c|}
\hline & $\begin{array}{c}\text { All } \\
\text { Infusions } \\
{[-30,-1]}\end{array}$ & $\begin{array}{c}\text { Infusions } \\
\text { where insiders } \\
\text { are Net Buyers } \\
\quad[-30,-1]\end{array}$ & $\begin{array}{c}\text { Infusions } \\
\text { where insiders } \\
\text { are Net Sellers } \\
\quad[-30,-1]\end{array}$ \\
\hline Variable & $\mathrm{N}=256$ & $\mathrm{~N}=89$ & $\mathrm{~N}=52$ \\
\hline Total \# Insiders Trading & 383.00 & 269.00 & 114.00 \\
\hline Total Insider Volume (\$ millions) & 118.43 & 63.08 & 55.35 \\
\hline $\begin{array}{l}\text { Avg. AnncRet } \\
\quad p \text {-value for test of differences }\end{array}$ & -0.40 & \multicolumn{2}{|c|}{$[0.38]$} \\
\hline $\begin{array}{l}\text { Avg. Infusion } \% M V \\
\quad p \text {-value for test of differences }\end{array}$ & 42.48 & \multicolumn{2}{|c|}{$[0.02]$} \\
\hline $\begin{array}{l}\text { Avg. Infusion } \% T A \\
p \text {-value for test of differences }\end{array}$ & 2.28 & \multicolumn{2}{|c|}{$[0.06]$} \\
\hline
\end{tabular}

Panel B. Infusion Characteristics Partitioned by Political Connections and Insider Trade

\begin{tabular}{|c|c|c|c|c|}
\hline \multirow[b]{3}{*}{ Variable } & \multicolumn{2}{|c|}{ Political Connections: Yes } & \multicolumn{2}{|c|}{ Political Connections: No } \\
\hline & $\begin{array}{l}\text { Net Buyers } \\
{[-30,-1]}\end{array}$ & $\begin{array}{l}\text { Net Sellers } \\
{[-30,-1]}\end{array}$ & $\begin{array}{l}\text { Net Buyers } \\
{[-30,-1]}\end{array}$ & $\begin{array}{c}\text { Net Sellers } \\
{[-30,-1]}\end{array}$ \\
\hline & $\mathrm{N}=32$ & $\mathrm{~N}=27$ & $\mathrm{~N}=57$ & $\mathrm{~N}=25$ \\
\hline Total \# Insiders Trading & 87.00 & 63.00 & 182.00 & 51.00 \\
\hline Total Insider Volume (\$ millions) & 55.31 & 49.24 & 7.77 & 6.11 \\
\hline $\begin{array}{l}\text { Avg. AnncRet } \\
\quad p \text {-value for test of differences }\end{array}$ & \multicolumn{2}{|c|}{$[<0.01]$} & \multicolumn{2}{|c|}{$[0.05]$} \\
\hline $\begin{array}{l}\text { Avg. Infusion } \% M V \\
\quad p \text {-value for test of differences }\end{array}$ & \multicolumn{2}{|c|}{$[0.03]$} & \multicolumn{2}{|c|}{$[0.16]$} \\
\hline $\begin{array}{l}\text { Avg. Infusion } \% T A \\
p \text {-value for test of differences }\end{array}$ & \multicolumn{2}{|c|}{$[0.22]$} & \multicolumn{2}{|c|}{$[0.06]$} \\
\hline
\end{tabular}


Table VII. Front-Running TARP Infusions (cont'd)

Panel C. Cross-Sectional Regressions

\begin{tabular}{lcccc}
\hline \multirow{2}{*}{} & \multicolumn{4}{c}{ Dependent variable: AnncRet } \\
\cline { 2 - 5 } & All & \multicolumn{3}{c}{ Political Connections } \\
Variables & Infusions & Yes & No & Diff \\
Buyer(-30,-1) & 1.11 & $(2)$ & $(3)$ & $(4)$ \\
Controls & $(0.76)$ & $(2.23)$ & $(-0.95)$ & {$[0.02]$} \\
Size & & & & \\
& -0.25 & -0.78 & 0.50 & -1.28 \\
BM & $(-0.61)$ & $(-1.46)$ & $(0.76)$ & {$[0.13]$} \\
& -1.26 & -2.00 & -0.21 & -1.79 \\
PastMoRet & $(-1.33)$ & $(-1.04)$ & $(-0.19)$ & {$[0.41]$} \\
& 0.01 & -0.10 & 0.07 & $-\mathbf{0 . 1 7}$ \\
PastYrRet & $(0.15)$ & $(-1.36)$ & $(1.23)$ & {$[0.07]$} \\
& -0.01 & -0.01 & -0.01 & 0.00 \\
F & $(-0.42)$ & $(-0.27)$ & $(-0.13)$ & {$[0.91]$} \\
N(firm-days) & 0.56 & 2.42 & 1.05 \\
N(firms) & 256 & 94 & 162 & \\
\hline \hline
\end{tabular}




\section{Table VIII. Front-Running TARP Infusions-Falsification Tests}

This table presents results from using two falsification tests to estimate the cross-sectional variation in announcement returns under the null hypothesis that it is unrelated to TARP infusions. Panel A presents results from the first falsification test. In the first falsification test, we hold the firms in the sample fixed (i.e., the set of TARP recipients), and estimate the regression specification in Table VII, Panel C, for the same firms on all non-announcement days from October 2008 to June 2009. We test whether the estimated coefficients from TARP recipients on the announcement day are different from those estimated from TARP recipients on non-announcement days. Sample of 249 unique firms across 188 non-event days. Panel B presents results from the second falsification test. In the second falsification test, we hold the event dates in the sample fixed, and estimate the regression specification in Table VII, Panel C, for the same dates for firms that did not receive TARP infusions. We test whether the estimated coefficients from TARP recipients on the announcement day are different from those estimated from non-recipients on the announcement day. Sample of 242 unique non-recipients across 31 announcement days. For parsimony, we do not tabulate coefficients on control variables. $t$-statistics (two-tailed $p$-values) based on standard errors clustered by firm appear in parentheses (brackets). ${ }^{* * *},{ }^{* *}$, and ${ }^{*}$ denote statistical significance at the $0.01,0.05$, and 0.10 levels (two-tail), respectively.

Panel A. Falsification Test \#1: TARP Recipients on Non-Announcement days

\begin{tabular}{|c|c|c|c|c|c|c|c|}
\hline \multirow[b]{3}{*}{ Variables } & \multicolumn{3}{|c|}{$\begin{array}{l}\text { TARP recipients } \\
\text { on the announcement day }\end{array}$} & \multicolumn{3}{|c|}{$\begin{array}{c}\text { FALSIFICATION: } \\
\text { TARP recipients } \\
\text { on the non-announcement dates }\end{array}$} & \multirow{3}{*}{$\begin{array}{c}\text { Diff } \\
\text {-in- } \\
\text { Diff } \\
(7)\end{array}$} \\
\hline & \multicolumn{2}{|c|}{$\begin{array}{c}\text { Political } \\
\text { Connections }\end{array}$} & \multirow[b]{2}{*}{$\begin{array}{l}\text { Diff } \\
(3) \\
\end{array}$} & \multicolumn{2}{|c|}{$\begin{array}{c}\text { Political } \\
\text { Connections }\end{array}$} & \multirow[b]{2}{*}{$\begin{array}{c}\text { Diff } \\
(6) \\
\end{array}$} & \\
\hline & $\begin{array}{l}\text { Yes } \\
(1)\end{array}$ & $\begin{array}{l}\text { No } \\
(2) \\
\end{array}$ & & $\begin{array}{l}\text { Yes } \\
(4)\end{array}$ & $\begin{array}{l}\text { No } \\
(5) \\
\end{array}$ & & \\
\hline Buyer $(-30,-1)$ & $\begin{array}{l}5.41^{* * *} \\
(2.23)\end{array}$ & $\begin{array}{c}-1.67 \\
(-0.95)\end{array}$ & $\begin{array}{l}7.08^{* *} \\
{[0.02]}\end{array}$ & $\begin{array}{l}1.32^{* * *} \\
(5.83)\end{array}$ & $\begin{array}{c}\mathbf{0 . 6 7} \\
(3.79)\end{array}$ & $\begin{array}{l}\mathbf{0 . 6 5} 5^{* *} \\
{[0.03]}\end{array}$ & $\begin{array}{l}6.43^{* *} \\
{[0.03]}\end{array}$ \\
\hline Controls & Yes & Yes & & Yes & Yes & & \\
\hline $\mathrm{F}$ & 2.42 & 1.05 & & 25.00 & 14.34 & & \\
\hline N(firm-days) & 94 & 162 & & 17,201 & 29,242 & & \\
\hline $\mathrm{N}$ (firms) & 92 & 157 & & 92 & 157 & & \\
\hline
\end{tabular}

Panel B. Falsification Test \#2: Non-Recipients on Announcement days

\begin{tabular}{|c|c|c|c|c|c|c|c|}
\hline \multirow[b]{3}{*}{ Variables } & \multirow{2}{*}{\multicolumn{3}{|c|}{$\begin{array}{l}\text { TARP recipients } \\
\text { on the announcement day } \\
\text { (Table VII, Panel C) } \\
\text { Political } \\
\text { Connections }\end{array}$}} & \multirow{2}{*}{\multicolumn{3}{|c|}{$\begin{array}{l}\text { FALSIFICATION: } \\
\text { Non-recipients } \\
\text { on the announcement dates } \\
\text { Political } \\
\text { Connections }\end{array}$}} & \multirow{3}{*}{$\begin{array}{c}\text { Diff } \\
\text {-in- } \\
\text { Diff } \\
(7)\end{array}$} \\
\hline & & & & & & & \\
\hline & $\begin{array}{l}\text { Yes } \\
(1)\end{array}$ & $\begin{array}{l}\text { No } \\
(2)\end{array}$ & $\begin{array}{c}\text { Diff } \\
(3)\end{array}$ & $\begin{array}{l}\text { Yes } \\
(4)\end{array}$ & $\begin{array}{l}\text { No } \\
(5)\end{array}$ & $\begin{array}{c}\text { Diff } \\
(6)\end{array}$ & \\
\hline Buyer $(-30,-1)$ & $\begin{array}{l}\mathbf{5 . 4 1} \\
(2.23)\end{array}$ & $\begin{array}{c}-1.67 \\
(-0.95)\end{array}$ & $\begin{array}{l}7.08^{* * *} \\
{[0.02]}\end{array}$ & $\begin{array}{c}0.14 \\
(0.28) \\
\end{array}$ & $\begin{array}{l}\mathbf{0 . 6 5} 5^{* *} \\
(2.14)\end{array}$ & $\begin{array}{l}-0.51 \\
{[0.38]}\end{array}$ & $\begin{array}{l}7.59^{* * *} \\
{[0.01]}\end{array}$ \\
\hline Controls & Yes & Yes & & Yes & Yes & & \\
\hline $\mathrm{F}$ & 2.42 & 1.05 & & 4.46 & 3.29 & & \\
\hline $\mathrm{N}$ (firm-days) & 94 & 162 & & 1,958 & 5,224 & & \\
\hline $\mathrm{N}$ (firms) & 92 & 157 & & 66 & 176 & & \\
\hline
\end{tabular}




\section{Table IX. Front-Running TARP Infusions-Comparison to Other Information Events}

This table presents results from repeating our event study tests on other news events during the Crisis. Panel A presents results from estimating the specification of Panel $\mathrm{C}$ of Table VII after replacing the infusion date with the earnings announcement date. Sample of 1,619 earnings announcements between July 2007 and June 2009 for 249 TARP recipients. Panel B presents results from estimating the specification of Panel C of Table VII after replacing the infusion date with the date during the Crisis that has the largest absolute return. Sample of 249 extreme returns between July 2007 and June 2009. For parsimony, we do not tabulate coefficients on control variables. $t$-statistics (two-tailed p-values) based on standard errors clustered by firm appear in parentheses (brackets). ${ }^{* * *},{ }^{* *}$, and ${ }^{*}$ denote statistical significance at the $0.01,0.05$, and 0.10 levels (two-tail), respectively.

\section{Panel A. Front-Running Earnings Announcement}

\begin{tabular}{|c|c|c|c|c|c|c|c|}
\hline \multirow[b]{3}{*}{ Variables } & \multirow{2}{*}{\multicolumn{3}{|c|}{$\begin{array}{l}\text { TARP Recipients' infusions } \\
\text { announcements } \\
\text { (Table VII, Panel C) } \\
\text { Political } \\
\text { Connections } \\
\end{array}$}} & \multicolumn{3}{|c|}{$\begin{array}{l}\text { TARP Recipients' } \\
\text { earnings announcements }\end{array}$} & \multirow{3}{*}{$\begin{array}{c}\text { Diff } \\
\text {-in- } \\
\text { Diff } \\
(7)\end{array}$} \\
\hline & & & & \multicolumn{2}{|c|}{$\begin{array}{c}\text { Political } \\
\text { Connections } \\
\end{array}$} & \multirow[b]{2}{*}{$\begin{array}{l}\text { Diff } \\
(6)\end{array}$} & \\
\hline & $\begin{array}{l}\text { Yes } \\
(1)\end{array}$ & $\begin{array}{l}\text { No } \\
(2)\end{array}$ & $\begin{array}{l}\text { Diff } \\
(3)\end{array}$ & $\begin{array}{l}\text { Yes } \\
(4)\end{array}$ & $\begin{array}{l}\text { No } \\
(5)\end{array}$ & & \\
\hline Buyer $(-30,-1)$ & $\begin{array}{l}5.41^{* * *} \\
(2.23)\end{array}$ & $\begin{array}{l}-1.67 \\
(-0.95)\end{array}$ & $\begin{array}{l}7.08^{* * *} \\
{[0.02]}\end{array}$ & $\begin{array}{c}0.65 \\
(0.62) \\
\end{array}$ & $\begin{array}{l}-0.09 \\
(-0.14)\end{array}$ & $\begin{array}{c}0.74 \\
{[0.60]}\end{array}$ & $\begin{array}{l}6.34^{* *} \\
{[0.04]}\end{array}$ \\
\hline Controls & Yes & Yes & & Yes & Yes & & \\
\hline $\mathrm{F}$ & 2.42 & 1.05 & & 5.74 & 4.18 & & \\
\hline N(firm-days) & 94 & 162 & & 604 & 1015 & & \\
\hline $\mathrm{N}($ firms $)$ & 92 & 157 & & 92 & 157 & & \\
\hline
\end{tabular}

Panel B. Front-Running Extreme Return Days

\begin{tabular}{|c|c|c|c|c|c|c|c|}
\hline \multirow[b]{3}{*}{ Variables } & \multirow{2}{*}{\multicolumn{3}{|c|}{$\begin{array}{l}\text { TARP Recipients' infusions } \\
\text { announcements } \\
\text { (Table VII, Panel C) } \\
\text { Political } \\
\text { Connections } \\
\end{array}$}} & \multicolumn{3}{|c|}{$\begin{array}{l}\text { TARP Recipients' } \\
\text { Most extreme news day }\end{array}$} & \multirow{3}{*}{$\begin{array}{c}\text { Diff } \\
\text {-in- } \\
\text { Diff } \\
(7)\end{array}$} \\
\hline & & & & \multicolumn{2}{|c|}{$\begin{array}{c}\text { Political } \\
\text { Connections }\end{array}$} & \multirow[b]{2}{*}{$\begin{array}{c}\text { Diff } \\
(6)\end{array}$} & \\
\hline & $\begin{array}{l}\text { Yes } \\
(1)\end{array}$ & $\begin{array}{l}\text { No } \\
\text { (2) }\end{array}$ & $\begin{array}{l}\text { Diff } \\
\text { (3) }\end{array}$ & $\begin{array}{l}\text { Yes } \\
(4)\end{array}$ & $\begin{array}{l}\text { No } \\
(5)\end{array}$ & & \\
\hline Buyer $(-30,-1)$ & $\begin{array}{l}\mathbf{5 . 4 1}^{* *} \\
(2.23)\end{array}$ & $\begin{array}{l}-1.67 \\
(-0.95)\end{array}$ & $\begin{array}{l}7.088^{* *} \\
{[0.02]}\end{array}$ & $\begin{array}{c}-\mathbf{1 3 . 9 4}^{* *} \\
(-2.34)\end{array}$ & $\begin{array}{l}-4.77 \\
(-0.79)\end{array}$ & $\begin{array}{l}-9.17 \\
{[0.28]}\end{array}$ & $\begin{array}{l}\mathbf{1 6 . 2 5} \\
{[1.80]}\end{array}$ \\
\hline Controls & Yes & Yes & & Yes & Yes & & \\
\hline $\mathrm{F}$ & 2.42 & 1.05 & & 8.56 & 3.73 & & \\
\hline N(firm-days) & 94 & 162 & & 92 & 157 & & \\
\hline $\mathrm{N}$ (firms) & 92 & 157 & & 92 & 157 & & \\
\hline
\end{tabular}




\section{Table X. Front-Running TARP Infusions-Evidence from FOIA Data}

This table presents descriptive statistics on the amount of funds requested by the firm and its relation to insider trading activity 30 days prior to the infusion. Data on requested funds was obtained through a Freedom of Information Act (FOIA) request to the Treasury Department. Panel A presents distributional statistics on the amount of funds requested (Application), the amount of funds received (Infusion), and ratio of received to requested funds (Ratio = Infusion / Application). Application and Infusion are expressed in millions. Panel B presents descriptive statistics for each of three terciles of Ratio: infusions where Ratio $<1$; Ratio $=1$; and Ratio $>1$. Panel C presents results from estimating the direction of insider trade 30 days prior to the infusion (Buyer $(-30,-1))$ as function of the subsequent market reaction to the infusion (AnncRet), and the tercile rank of the wedge between infusion and application amounts (Ratio). Sample of 105 infusions where insiders trade more than $\$ 10,000$ over the 30 days before the infusion. $t$-statistics based on standard errors clustered by firm appear in parentheses. ${ }^{* * *},{ }^{* *}$, and ${ }^{*}$ denote statistical significance at the $0.01,0.05$, and 0.10 levels (two-tail), respectively.

Panel A. Descriptive Statistics on Application and Infusion Amounts

\begin{tabular}{lrrrrrrrrr}
\hline \hline & & \multicolumn{8}{c}{ Percentile } \\
Variable & \multicolumn{1}{c}{ Mean } & \multicolumn{1}{c}{ Std } & \multicolumn{1}{c}{$1^{\text {st }}$} & \multicolumn{1}{c}{$5^{\text {th }}$} & \multicolumn{1}{c}{$25^{\text {th }}$} & \multicolumn{1}{c}{$50^{\text {th }}$} & \multicolumn{1}{c}{$75^{\text {th }}$} & \multicolumn{1}{c}{$95^{\text {th }}$} & \multicolumn{1}{c}{$99^{\text {th }}$} \\
\hline Application & 374.19 & 1121.00 & 7.00 & 9.00 & 23.18 & 48.20 & 135.00 & 2250.00 & 6599.00 \\
Infusion & 372.46 & 1114.00 & 7.00 & 9.00 & 23.18 & 48.20 & 135.00 & 2250.00 & 6599.00 \\
Ratio & 0.99 & 0.05 & 0.71 & 0.97 & 1.00 & 1.00 & 1.00 & 1.00 & 1.02 \\
\hline \hline
\end{tabular}

Panel B. Insider Trading and Political Connections

\begin{tabular}{lccc}
\hline \hline & $\begin{array}{c}\text { Ratio }<1 \\
\mathrm{~N}=11 \\
\text { infusions }\end{array}$ & $\begin{array}{c}\text { Ratio }=1 \\
\mathrm{~N}=91 \\
\text { infusions }\end{array}$ & $\begin{array}{c}\text { Ratio }>1 \\
\mathrm{~N}=3 \\
\text { infusions }\end{array}$ \\
Variable & 0.91 & 1.00 & 1.03 \\
Average Ratio & 0.73 & 0.40 & 0.33 \\
Average Connected & 0.45 & 0.60 & 1.00 \\
\hline \hline
\end{tabular}


Table X. Front-Running TARP Infusions—Evidence from FOIA Data (cont'd)

Panel C. Determinants of Front-Running

\begin{tabular}{|c|c|c|c|}
\hline \multirow[b]{2}{*}{ Variables } & \multicolumn{3}{|c|}{ Dependent Variable: Buyer $(-30,-1)$} \\
\hline & $\begin{array}{c}\text { All observations } \\
\text { (1) }\end{array}$ & $\begin{array}{c}\text { Political } \\
\text { Connections: Yes } \\
(2) \\
\end{array}$ & $\begin{array}{c}\text { Political } \\
\text { Connections: No } \\
(3) \\
\end{array}$ \\
\hline AnncRet & $\begin{array}{l}\mathbf{0 . 0 1}^{*} \\
(1.84)\end{array}$ & $\begin{array}{l}\mathbf{0 . 0 1}^{* * * *} \\
(2.61)\end{array}$ & $\begin{array}{l}0.002 \\
(0.40)\end{array}$ \\
\hline Ratio & $\begin{array}{l}\mathbf{0 . 1 6}{ }^{* *} \\
(2.22)\end{array}$ & $\begin{array}{l}\mathbf{0 . 2 6} 6^{* * * *} \\
(2.96)\end{array}$ & $\begin{array}{c}0.17 \\
(1.36)\end{array}$ \\
\hline \multicolumn{4}{|l|}{ Controls } \\
\hline Buyer $(-60,-31)$ & $\begin{array}{l}\mathbf{0 . 2 0}^{* *} \\
(2.44)\end{array}$ & $\begin{array}{c}0.13 \\
(1.02)\end{array}$ & $\begin{array}{c}\mathbf{0 . 2 1}{ }^{*} \\
(1.91)\end{array}$ \\
\hline Size & $\begin{array}{c}-\mathbf{0 . 1 1} 1^{* * *} \\
(-4.58)\end{array}$ & $\begin{array}{c}-\mathbf{0 . 1 2} 2^{* * * *} \\
(-4.34)\end{array}$ & $\begin{array}{l}-\mathbf{0 . 1 2} \mathbf{1}^{* *} \\
(-2.14)\end{array}$ \\
\hline$B M$ & $\begin{array}{c}0.04 \\
(0.58)\end{array}$ & $\begin{array}{c}-\mathbf{0 . 3 8}^{* * * *} \\
(-2.81)\end{array}$ & $\begin{array}{c}0.13 \\
(1.36)\end{array}$ \\
\hline PastMoRet & $\begin{array}{c}-\mathbf{0 . 0 1}{ }^{* * *} \\
(-2.66)\end{array}$ & $\begin{array}{l}-0.003 \\
(-0.96)\end{array}$ & $\begin{array}{l}-0.01 \\
(-1.38)\end{array}$ \\
\hline PastYrRet & $\begin{array}{l}-\mathbf{0 . 0 1}{ }^{* * *} \\
(-2.11)\end{array}$ & $\begin{array}{c}-\mathbf{0 . 0 1}{ }^{* * *} \\
(-4.33)\end{array}$ & $\begin{array}{l}-0.001 \\
(-0.33) \\
\end{array}$ \\
\hline $\mathrm{F}$ & 29.04 & 30.77 & 8.13 \\
\hline N(firm-days) & 105 & 45 & 60 \\
\hline $\mathrm{N}$ (firms) & 105 & 45 & 60 \\
\hline
\end{tabular}

